\title{
Plantar povoações no território: (re)/construindo a urbanização da capitania do Piauí, $1697-1761^{1}$
}

\begin{abstract}
Esdras Arraes ${ }^{2}$
RESUMO: A urbanização da capitania do Piauí acompanhou, desde finais do século XVII, um complexo processo negociado entre a Coroa portuguesa, os representantes régios, a rede clientelar urdida pela Casa da Torre e a população residente em seus sertões. $\bigcirc$ que antes era conteúdo dos sertões de Rodelas passou a construir-se como identidade territorial a partir da fundação da primeira freguesia, em 1697, dedicada a Nossa Senhora da Vitória. Estruturando-se descontinuamente no tempo e no espaço, o Piauí reforma-se em 1758, ano da autonomização do seu governo. E fez-se urbano em 1761, quando D. José I e o marquês de Pombal equacionaram, por meio da carta régia de 19 de junho, um território formado por seis vilas e uma cidade. Nessa direção, o objetivo deste artigo consiste em reconstruir o processo de formação da capitania do Piauí segundo os agentes envolvidos na urbanização do território. Propõe-se descortinar as políticas da Coroa por meio da oficialização de povoações estrategicamente locadas no território visando o controle e o "remédio" das injustiças rotineiras do Piauí. $O$ método de apresentar essa reconstrução vale-se da interconexão entre texto (documentação manuscrita) e imagem (mapas e fotografias), que em suas entrelinhas representam um Piauí como espaço de experiências sentidas tanto na dimensão oficial quanto no cotidiano dos seus moradores.

PALAVRAS-CHAVE: Cartografia. Piauí. Política Territorial. Rede Urbana. Sertões do Norte. Urbanização.

ABSTRACT: The Piaui province's urbanization has kept up with since late $17^{\text {th }}$ century a complex process dealt among Portuguese Crown, the regal representatives, the network woven by the Casa da Torre and by the resident population in its countryside. What it was content of Rodelas countryside has begun to build with territorial identity since the foundation of first parish in 1697. Structuring itself discontinuously in time and space, the Piaui had reformed in 1758, year of creation of its autonomous government. And had became urban in 1761 when the king D. José I and marquis of Pombal had framed by the royal letter written in June 19 a territory formed by six towns and one city. Thus, this paper purposes to reconstructing the Piauí province according
\end{abstract}

Anais do Museu Paulista. São Paulo. N. Sér. v.24. n.1. p. 257-298. jan.- abr. 2016.

1. Este ensaio faz parte de uma pesquisa mais ampla desenvolvida junto à Faculdade de Arquitetura e Urbanismo da Universidade de São Paulo (FAU USP), em nível de doutorado. Agradeço à Fundação de Amparo à Pesquisa do Estado de São Paulo (FAPESP) pela bolsa BEPE que proporcionou o acesso à documentação guardada nos arquivos de Portugal.

2. Arquiteto, doutorando na Faculdade de Arquitetura e Urbanismo da Universidade de São Paulo. E-mail: <esdrasarraes@gmail.com>

Anais do Museu Paulista. São Paulo. N. Sér. v.24. n.1. p. 257-298. jan.-abr. 2016. 
3. Cf. Ernesto Ennes (1938, p. 349-350).

4. Ver Maria Cristina Pompa (2011, p. 267). to agents involved in the urbanization processes. It proposes to deconstructing Crown's polices by means towns strategically placed in territory aiming at control and "remedy" of routine injustices practiced in Piauí's hinterlands. The method of presenting this reconstruction draws on interconnection between text (manuscript documents) and image (maps and photography) which in their discourses have represented a Piauí as space of experiences apprehended as much in official dimension as inhabitant's everyday life.

KEYWORDS: Cartography. Piauí. Territorial policy. Urban network. Northern Hinterlands. Urbanization.

No princípio eram os sertões de Rodelas...

Em consulta de 12 de dezembro de 1697, o Conselho Ultramarino relatava ao rei, D. Pedro II, sobre uma carta escrita pelo bispo D. Frei Francisco de Lima e por Caetano de Melo e Castro, governador da capitania de Pernambuco, em que davam conta das irregularidades dos sertões de Rodelas decorrentes da reduzida quantidade de povoações, da desarmônica distribuição de sesmarias, da violência praticada pela população habitante da região, assim como pela baixa fiscalização na cobrança dos dízimos eclesiásticos. Fazia-se urgente, naquela altura, "...povoarem aquellas terraz, reduziondoas a Collonias, e Povoações, sendo este meyo, não só de segurarem aquelles Certoens com estas defenças, mas tambem o de poder lucrar grandez conveniençias a fazenda de V.Mag. ${ }^{\text {de }}$ nos dizimos que se podem tirar da Cultura dellas..." 3.

Diante desse quadro, os propósitos ulteriores da política régia deveriam se orientar pelo incentivo à ocupação efetiva do território, traduzida na fundação de povoações oficiais e no cultivo da terra. Essa metodologia buscava desembaraçar as injustiças rotineiras nos sertões das capitanias do Norte, onde as povoações seriam utilizadas pela Coroa portuguesa para controlar, fiscalizar e vigiar áreas fragilmente delimitadas e senhoreadas por uma poderosa rede de homens residentes no litoral e Recôncavo baianos. Enquadram-se nesse grupo a família Dias d'Ávila (a Casa da Torre), a família Guedes de Brito (a Casa da Ponte), Domingos Afonso Mafrense (depois apropriadamente alcunhado de Sertão), João Jorge Afonso e os representantes da Companhia de Jesus do Colégio de Salvador.

Os novos assentamentos reformariam os sertões, transformando-os de vastidões incertas em territórios devidamente ocupados e definidos. $\bigcirc$ que se conhecia até aqueles finais do Seiscentos decorria de relatos fragmentados feitos ou escritos por religiosos, índios e sertanistas. Narrativas muitas vezes paradoxais e fantasiosas, nas quais os sertões apresentavam-se ora como terras de riquezas minerais, ora como o locus da barbárie. Ali habitavam os Tapuias, um diversificado número de etnias ameríndias que, segundo os cronistas do século XVI, eram contrárias aos processos de colonização agenciados pela Coroa. Segundo Maria Cristina Pompa, o termo "Tapuia" não seria um etnômino, mas uma construção ideológica colonial ${ }^{4}$. $\bigcirc$ mundo Tapuia foi pensado em oposição ao mundo Tupi. 
Enquanto que este estava mais disposto a aceitar a colonização e suas especificidades, naquele figuravam rupturas e tensões, eram os "bárbaros" habitantes de áreas desconhecidas e indômitas, sendo a representação da alteridade humana radical presente em todo o discurso colonial.

Os sertões de Rodelas era uma região com limites imprecisos, complexa em aspectos socioculturais e heterogênea no âmbito biogeográfico, abrigando desde secas caatingas aos vales férteis de carnaúbas e buritis. Contudo, de acordo com a documentação compulsada, pode-se imaginar sua extensão aproximada, tomando como balizas alguns elementos do mundo físico, rios e montanhas, essencialmente. Ainda em 1697, o bispo e o governador de Pernambuco disseram que "...o sertão que chamão de Rodella, q' pellas travessias de q' he cursado contem mais de 400 legoas cortado de varios Rios, huns menos, e outros mais caudelosos, porem todos de boas agoas, o clima he $m .^{\text {to }}$ saudavel, e não menos fértil a terra p. a criação, e sustento dos gados..." 5 . $\bigcirc$ rio São Francisco foi a principal geratriz na formação de Rodelas: a sul, esses sertões alcançavam o rio Carinhanha; a oeste, limitavam-se, talvez, com o rio Parnaíba, já em terras da futura capitania do Piauí; a sudeste, abraçavam parte da serra da Jacobina, outra localidade carregada de fábulas divulgadas por agentes de procedências culturais variadas; e, a leste, culminavam no encontro dos rios Moxotó e São Francisco, ou quem sabe, na cachoeira de Paulo Afonso (Figura 01 ).

Esses sertões já haviam sido povoados, modificados e cultivados (para os dois últimos processos deve-se atentar às devidas técnicas empregadas) por diversas tribos indígenas antes da chegada do europeu. $\bigcirc$ colono português soube reinterpretar e reutilizar o território deixando "marcas" materiais e simbólicas, seja na escolha do sítio onde seriam implantadas as povoações ou na edificação de arquiteturas pias. Sobre as tribos que habitavam essas zonas interiorizadas, Gabriel Soares de Sousa relatou que os índios eram "...tantos e estão tão divididos em bandos, costumes e linguagens, para se poder dizer deles muito, era necessário de propósito e devagar tomar grandes informações de suas divisões, vidas e costumes..." ". Sabe-se da existência de múltiplas comunidades como os Amoipiras, Cariris, Orises, Procases, Tocós, Moritises, Sapoiás e Païaiás ${ }^{7}$. Na ribeira do rio Salitre, o governador geral do Brasil, D. Rodrigo da Costa, incentivou, em 1703, "guerra justa" contra os Macarus em áreas de extração do salitre ${ }^{8}$. $\bigcirc$ padre Miguel de Carvalho arrolou 36 outras etnias dispostas nas ribeiras de rios como o Piauí, Canindé, Parnaíba, Sambito, Itaim e Gurguéia? . Cronistas como Gabriel de Sousa 10 e Sebastião da Rocha Pita ${ }^{11}$ mencionaram um tronco familiar comum para muitas dessas tribos, como os Amoipira descendentes dos Tupinambá e habitantes das margens sanfranciscanas. $\bigcirc$ surgimento ou a (re)invenção de novas comunidades nativas era um processo social habitual entre os índios do Brasil. Conforme mostrou John Monteiro ${ }^{12}$, a gênese de etnias, ou etnogênese, seria uma combinação de estratégias políticas e culturais de agentes nativos buscando (re)criar identidades num contexto de descontinuidade e mudanças radicais. Por isso, os índios não apresentaram culturas estanques, sem dinâmica própria. Pode-se dizer, sobre esses
5. Cf. Arquivo Histórico Ultramarino_Administração Central_ Conse 1 h o Ultramarino_Pernambuco, Cx. 17. D. 1732.

6. Cf. Gabriel Soares de Sousa (1971, p. 338).

7. Ver Serafim Leite (1945, p. 271).

8. Cf. Arquivo Histórico Ultramarino_Administração Central_Conselho Ultramarino_Pernambuco, Cx. 20, D. 1941.

9. Ver Ernesto Ennes (1938, p. 387-389).

10. Ver Gabriel Soares de Sousa (1971).

11. Ver Sebastião da Rocha Pita (1976).

12. Ver John Monteiro (2001, p.56). 


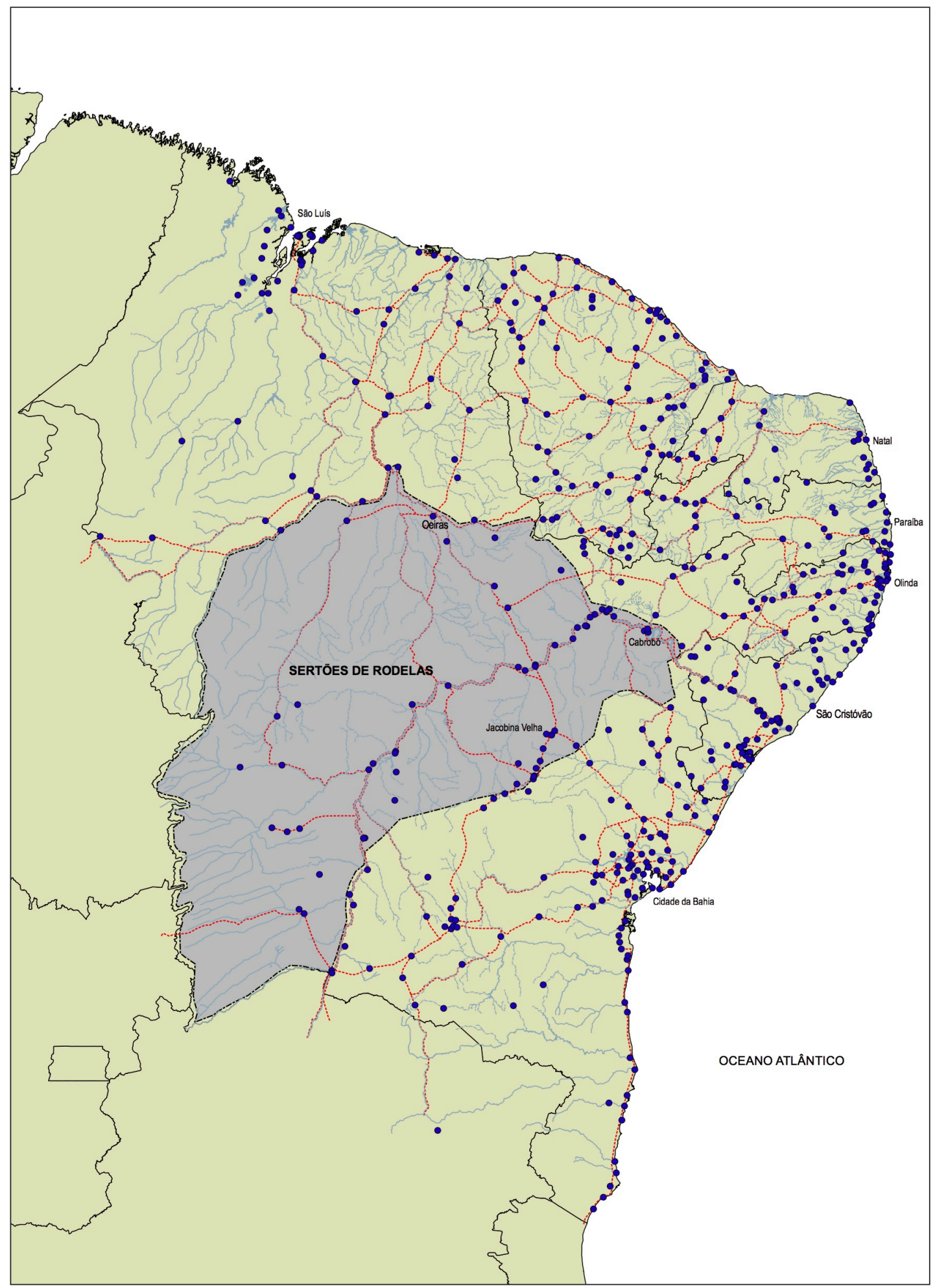

Figura 1 - Território aproximado e imaginado do que seriam os Sertões de Rodelas. Desenho do autor segundo informações retiradas dos manuscritos do Arquivo Histórico Ultramarino de Lisboa. 
aspectos, que o topônimo "Rodelas" homogeneizou a sua complexidade étnicocultural, o que talvez facilitasse as políticas régias de controle, urbanização e fragmentação daquele território.

Até 1696, a freguesia de Nossa Senhora da Conceição de Cabrobó parece ser a única povoação dos sertões de Rodelas oficializada pela Coroa. $\bigcirc$ documento mais recuado no tempo que lhe faz referência é o "Relatório de visita ad limina do bispo de Pernambuco D. Matias de Figueiredo e Melo, datado de julho de 1693"13. É interessante mencionar que, a partir de 1671, o Estado português aprovou a implantação de aldeamentos missioneiros em pontos nevrálgicos do rio São Francisco, em especial em áreas de conflito fundiário com a Casa da Torre ou nas proximidades das minas de salitre. Não cabe aqui tratar desse assunto já discutido em trabalhos anteriores ${ }^{14}$. Mas, deve-se traçar o papel da paróquia de Cabrobó na formação do Piauí, pois dela derivou a primeira igreja matriz dos seus sertões dedicada à Nossa Senhora da Vitória, núcleo embrionário da futura vila da Mocha e cidade de Oeiras do Piauí.

\section{A freguesia de Nossa Senhora da Vitória}

A estruturação de uma rede de freguesias (ou paróquias) nos sertões do bispado de Pernambuco foi uma das medidas adotadas pela Coroa no intuito de "remediar" os problemas sociais vigentes naqueles últimos anos do século XVII. As paróquias foram circunscrições territoriais decisivas no enquadramento político do espaço, tanto no Reino de Portugal, conforme os estudos de António Manuel Hespanha e Ana Cristina Nogueira da Silva, como na colônia da América, de acordo com as mais recentes investigações levadas a cabo por pesquisadores brasileiros ${ }^{15}$. Refletir sobre a oficialização de uma freguesia ou a formação de uma rede eclesiástica de paróquias no Brasil colonial requer a análise dos acordos negociados entre a Igreja Católica e a monarquia portuguesa no âmbito do padroado, e aqui esboçaremos algumas de suas políticas.

$\bigcirc$ padroado régio foi o acordo por meio do qual a Coroa exerceu sua função de "protetora" do catolicismo em seus domínios ultramarinos e como religião oficial de todos os povos conquistados ${ }^{16}$. Por meio de sucessivas bulas, os pontífices concederam privilégios aos reis portugueses em decorrência do apoio a que se dispuseram para promover a cristandade, junto com seus interesses econômicos e políticos, a novos horizontes geográficos ${ }^{17}$. Com isso, a Coroa estabelecia as diretrizes da ação da lgreja, transformando a evangelização num assunto do Estado, ou dito de outra forma, o uso da fé como um instrumento de expansão dominial ${ }^{18}$.

A autoridade papal tornou-se relativamente menor na colônia diante dos poderes concedidos ao monarca como chefe da lgreja. A função da Santa Sé limitava-se a confirmar as nomeações de cargos, funções e circunscrições eclesiásticas requisitadas pela Coroa ${ }^{19}$. Nenhum clérigo poderia sair do reino sem
13. Ver Patrícia Moreira Nogueira (2015, p. 10-16).

14. Ver Esdras Arraes (2014).

15. Ver os estudos dos historiadores portugueses Ana Cristina Nogueira da Silva; António Manuel Hespanha (1998). Assim como dos pesquisadores brasileiros Murillo Marx (1991), Cláudia Damasceno Fonseca (2011, p. 82-130), Maria Fernanda Derntl (2010, p. 62-71), Esdras Arraes (2012).

16. Ver Riolando Azzi (2008, p. 162).

17. Ver Arlindo Rubert (1992, p. 39).

18. Ver Caio César Boschi (1986, p. 86).

19. Ver Riolando Azzi (2008, p. 170). 
20. Ver Ibid. (p. 163).

21. Ver Sebastião Monteiro da Vide (2011, p. 252).

22. Cf. Ernesto Ennes (1938, p. 362).

23. Cf. Ibid. (p. 382).

24. Cf. Ibid. (p. 360) autorização régia e juramento de fidelidade ao rei. Em contrapartida, ao rei cabia a arrecadação dos dízimos, a seleção de arcebispos, bispos, cônegos e vigários colados. Incluía-se, ainda, a criação de novos arcebispados, bispados, prelazias e freguesias com suas respectivas circunscrições e zelar pela construção e conservação dos edifícios do culto divino como igrejas, capelas reais, conventos e palácios dos bispos ${ }^{20}$. Dessa forma, o reordenamento do território eclesiástico brasileiro, em suas variadas escalas, era expediente régio e acompanhou intimamente os seus interesses geopolíticos e econômicos.

Outra característica institucional das freguesias dizia respeito à publicação, em 1719, das Constituições Primeiras do Arcebispado da Bahia que aplicavam as disposições do Concílio de Trento (1545-1563) à realidade social brasileira. Essa normativa canônica orientou as autoridades eclesiásticas na promoção de capelas à qualidade de paróquias ou na eleição das povoaçães que pleiteavam esse status. Os critérios de escolhas não eram fortuitos, mas considerava-se a densidade populacional e questões econômicas das localidades pleiteantes. Por exemplo, o código 687 rezava que toda sede paroquial deveria ser construída em lugar povoado e onde estivesse o maior adensamento populacional ${ }^{21}$. Como veremos, a primeira freguesia criada no que seria a capitania do Piauí é anterior à homologação das Constituições, porém segue princípios normativos apontados em Trento. Lê-se no discurso do bispo de Pernambuco a conveniência do local escolhido pelos moradores e o número de habitantes como elementos basilares à oficialização da paróquia.

No final do Seiscentos, as comunicações envolvendo o Conselho Ultramarino e as autoridades de Pernambuco acentuavam a necessidade de dividir a imensa freguesia de Cabrobó em outra localizada no Piaú, "...p. a o bem [e]spiritual das almas, como tambem p. ${ }^{a}$ o augmento temporal deste Estado..."22. "Piaui", nessa altura, referia-se à ribeira do rio de mesmo nome: eixo hidrográfico de penetração àquele interior feito por Domingos Afonso Mafrense e procuradores da Casa da Torre, décadas antes, onde ergueram centenas de fazendas e currais de gado. Ou, como narrado pelo padre Miguel de Carvalho: "... $\circ$ Riacho Peauhy corre do sul p. ${ }^{\circ}$ o Norte entra no Canindê foi o pr. ${ }^{\circ}$ povoado de todo este Certão no anno de 1682, em que se descobrio, e delle tomou o nome"23. Não se relacionava, portanto, à capitania formalizada somente em 1718, desanexada da de Pernambuco e território subsidiário ao governo do Maranhão a partir de 1702.

O curato de Nossa Senhora da Vitória foi aprovado por ordem régia, cabendo aos fregueses o encargo "... de fazer, e aparamentar a lgreja, e dar ao Cura o Salario, que antes davão á Matriz [Cabrobó]..."24. A modalidade indicada - curato ou curato amovível la segunda nomeação era mais frequente nos documentos coevos) - apresentava algumas especificidades. Disseminaram-se por todos os sertões das capitanias do Norte, localizando-se nas proximidades dos caminhos terrestres e fluviais. A sua oficialização dependia da indicação do bispo e da aprovação da Coroa sem, contudo, ser necessário prévio concurso para a 
escolha dos curas. Afinal, o léxico associado à qualidade - "amovível"- traduz tudo aquilo que "se pode tirar quem o dá; não collado" 25 , isto é, os padres eram encaminhados às suas respectivas igrejas ou re-designados para outras de acordo com o interesse das autoridades eclesiásticas que, por seu turno, era-o também da Coroa. Nessa modalidade os párocos eram sustentados pelos paroquianos comprometidos em ofertar as "conhecenças" que lhes cabiam e os direitos de pé de altar ${ }^{26}$, um emolumento pago pelos batismos, matrimônios e enterros. Já a freguesia colada era uma categoria concedida diretamente pelo rei após criteriosa seleção de igrejas e párocos, e sua escolha não era feita ao acaso ${ }^{27}$. Ao contrário dos sacerdotes dos curatos amovíveis, os vigários colados atuavam como "filhos da folha eclesiástica" da Fazenda Real, recebendo a côngrua anual com valor entre 50 e 200 mil réis.

D. Frei Francisco de Lima ordenou o padre Miguel de Carvalho para congregar os moradores a fim de escolherem um sítio adequado para o templo de Nossa Senhora da Vitória. Em 11 de fevereiro de 1697, esses "homens-bons" da região ${ }^{28}$ (talvez procuradores ou rendeiros da Casa da Torre ou de Domingos Afonso Mafrense) juntos com o sacerdote optaram "...que se fundaçe, e fizeçe lg. ia no Breyo, chamado a Mocha por ser a parte mais conveniente, ficando no meio della com iguais distancias, e Caminhos p. ${ }^{a}$ todos os riachos e partes povoadas,

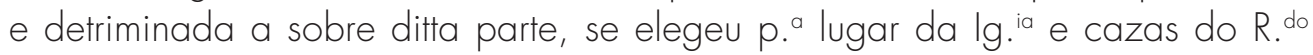
cura..." 29. A seleção do sítio da igreja era uma das facetas do cotidiano daqueles colonos, discutida previamente na fazenda Tranqueira, de António Soares Thouguia. A partir da nova arquitetura, caminhos foram abertos ligando os sítios e fazendas entre si e com as regiões adjacentes, movimentando as comunidades em relações que se alargariam ao longo do tempo.

O brejo da Mocha foi o local selecionado para a edificação do templo católico. Era um sítio "conveniente", ou seja, acessível por estar "no meio della [igreja] com iguais distançias, e caminhos", demandando deslocamentos mais curtos da população estruturada por cerca de 605 pessoas, entre índios, brancos, negros escravos e mestiços, distribuídas em 129 sedes de fazendas de gado vacum e cavalar ${ }^{30}$. Conveniente, também, no sentido de "decente" 31 , um lugar plano e nas proximidades de cursos fluviais. A urbanização de ribeiras caracterizou os processos de transformação dos indefinidos sertões em paisagens, com os rios desempenhando um papel preponderante na localização, no desenvolvimento e na imagem das povoações, conferindo-thes uma configuração específica e um valor simbólico determinante, em que a relação vicus $\times$ fluminis construiu um sistema indissociável ${ }^{32}$. Recordemos de cidades como São Luís do Maranhão, situada nas proximidades do rio Anil; de Recife implantada nas margens do rio Capibaribe; da vila de índios de Santa Maria, erigida na ribeira do rio São Francisco; de Aracati, projetada, em 1748, nas bordas do rio Jaguaribe, assim como muitos outros núcleos urbanos que viam os rios uma mediação ontológica. Pensa-se, desse modo, que a igreja de Nossa Senhora da Vitória foi construída segundo lógicas utilitárias e éticas, transparecendo nos discursos de sua paisagem original.
25. Cf. Antonio Moraes Silva (1813, p. 126).

26. Ver Dom Oscar de Oliveira (1964, p. 148).

27. Ver Cláudia Damasceno Fonseca (2011, p. 100).

28. Além do padre, o documento arrola os seguintes agentes: Joseph Gracia, António da Cunha Sotto Mayor, Francisco Bezerra Correa, João Álvares de Oliveira, Francisco Machado, Christóvão de Britto de S. Paijo, Antonio Soares Touguia, Francisco Cardoso da Roza, Pedro Nunes Pinheyro, Pedro Álvares de Oliveira, Antonio Dantes de Azevedo, Francisco Dias Siqueira e Antonio Nunnes Barreto. Por questões de método, os nomes foram transcritos de acordo com a ortografia da época.

29. Cf. Ernesto Ennes (1938, p. 364).

30. Cf. Ibid. (p. 370).

31. Ver Raphael Bluteau (1728, p. 526).

32. Ver Maria da Graça Amaral N. Saraiva (1987, p. 461). 
33. Cf. Ernesto Ennes (1938, p. 368).

34. Ver Pedro Puntoni (2002).

35. Ver Roberta Marx Delson (1997, p. 18).

36. Ver Dom Oscar de Oliveira (1964),

37. Ver Cláudia Damasceno Fonseca (2011).

38. Cf. ANTT, Arcebispado da Bahia, maço 03, caixa 03.
Thomé de Carvalho e Silva foi o primeiro sacerdote da freguesia. Desde a fundação e construção da pequena igreja, esse agente participou nas modificações simbólico-materiais da paisagem dos sertões do Piaúi. Na ribeira do rio Itaim, ele possuía fazendas e currais de gado. No princípio como paróquia, a fisionomia do arraial assemelhava-se a uma instalação rural, contando apenas com o templo católico e a casa do padre, cujo chão de terra foi demarcado no mesmo dia da delimitação do adro. De dimensões reduzidas, com 24 palmos de comprimento por 12 palmos de largura, isto é, um duplo quadrado, a igreja matriz foi contruída com materiais simples "... de taypa, e cuberta de pindoba por ser parte adonde não ha telhas..."33, e situada num terreno sacralizado de 100 passos de comprimento por 60 passos de largura.

O curato simbolizou mais que a expansão do catolicismo àqueles sertões indefinidos. Representou o escrutínio régio em territórios subordinados à autoridade dos senhores de terras, que equacionavam a ordem social vigente ancorada por relações clientelistas submetidas a regras estritas de dependência e lealdade, substanciadas no universo da violência ${ }^{34}$. Destarte, injustiça social, crimes e irregularidade fundiária formularam uma parte do cotidiano dos sertanejos subordinados a esse sistema de viver. Como frisado por Roberta Delson, tais zonas não poderiam ficar sem supervisão, cabendo à Coroa a homologação de medidas cabíveis ao funcionamento de um programa legislativo capaz de reformar as lógicas de manejar a terra ${ }^{35}$. Seria estendida a autoridade do rei às regiões antes controladas por uma elite residente no litoral baiano.

A relação entre a Coroa portuguesa e os sertões do Piauí se intensificou em 1700, quando o curato se tornou freguesia colada. A partir daquele momento, - padre foi convertido em vigário colado, participante anual da folha de pagamentos eclesiásticos da Fazenda Real. A colação da paróquia de Nossa Senhora da Vitória seguiu estratégias geopolíticas bastante precisas. Segundo Dom Oscar de Oliveira ${ }^{36}$, e reiterado por Cláudia Damasceno Fonseca ${ }^{37}$, o Estado português tinha interesse em restringi-las a fim de não pagar as côngruas, instalandoas quando convinha por algum motivo político-econômico, e, dessa forma, a eleição não era produto do acaso. De maneira que esse fenômeno apareceu com maior incidência nas zonas de plantação de açúcar de Pernambuco e Bahia e nas áreas de mineração de Minas Gerais. Nos sertões dos currais de gado, as colações foram pontuais até o terceiro quartel do século XVIII. Durante a administração de D. Rodrigo de Sousa Coutinho, a modalidade passou a ser comum em diferentes partes do interior das capitanias do Norte, quando D. Maria I ordenou, pelas cartas régias de 26 de outubro de 1795 e 06 de agosto de 1799, a conversão de todas as freguesias de índios e curatos amovíveis ao benefício de coladas ${ }^{38}$.

Tudo indica que a nomeação do primeiro vigário, Thomé Carvalho e Silva, tenha se pautado por dois motivos. $\bigcirc$ primeiro dizia respeito às especificidades das políticas régias implementadas relativas ao controle territorial e fundiário das zonas interiorizadas da capitania de Pernambuco. A segunda razão refere-se à colação como uma graça régia em razão dos empreendimentos à 
colonização portuguesa. Em 1699, Thomé Carvalho reuniu, " ...com dispendio do pouco q' tinha, algum povo, q' com nossas próprias mãos, a falta de offertas e cabedais fizemos outra igreja mayor, e com mais segurança, q' a antiga..." ${ }^{\prime 9}$. Além disso, ele estabeleceu três aldeamentos missioneiros em precisas partes do Piauí a favorecer a urbanização das ribeiras. Para a Coroa, o índio catequizado significava territórios propícios à expansão da pecuária e das fronteiras dos seus domínios. Com efeito, na envolvente do rio ltaim, o vigário congregou a nação dos Jaicós e Icós, dando-lhes por "...Missionario o Pe. Manuel da Sylveira Serpa; pello Rio Poty o invadião os valerosos Uruares a quem busquei para Missionario o Pe. Paschoal da SylveiraFroys, em cuja Aldeia meti tambem, depois de parochiado, o gentio Longa..." 40. Finalmente, na passagem de Santo Antônio, estratégico nó viário de condução das boiadas e trajeto de comerciantes para a capitania do Maranhão, foram introduzidos em missão religiosa os indígenas AnúpúrúGoaçú e Meri sob a tutela do cura Manoel Oliveira Teyo ${ }^{41}$.

A mudança de hierarquia da paróquia passava o ônus de sustentar o padre e as reparações estruturais da igreja dos paroquianos ao poder régio. $\bigcirc$ novo status permitiu a substituição das paredes de taipa por estruturas de pedra. As alterações arquitetônicas efetivadas por volta de 1728 repercutiram não só na escala do edifício como também na paisagem urbana da freguesia. Nesse ano, já com o predicamento de vila adquirido em 1712, havia cerca de 90 moradias "...e alguãs por fora, que farão cento e vinte..." 42 , além da igreja matriz, do açougue público e da praça que definiam o viver diário dos vizinhos.

Antes de percorrer os meandros da urbanização da vila da Mocha e das tramas sociais e econômicas articuladas em sua autonomização, trataremos de sua qualidade de "julgado", um dos posicionamentos da rede de assentamentos humanos urdida em especial nos sertões do Brasil, só recentemente explorado nos estudos de História da Urbanização.

\section{julgado da freguesia de Nossa Senhora da Vitória}

Dom Frei Francisco de Lima e Caetano de Melo de Castro, nas suas missivas remetidas em 1697 a D. Pedro II e ao Conselho Ultramarino, argumentaram sobre a fragilidade do sistema judiciário dos sertões de Rodelas. Um território no qual o exercício da justiça era arbitrário e, em certa medida, subjugado à Casa da Torre e seus associados. As autoridades de Pernambuco indicaram que o "remédio" às instabilidades das freguesias e ribeiras seria "... que se ordene que de sinco em sinco legoas, haia hum Juiz ordinario com jurisdição para tirar devassas, tomar denunciações, e querellaz nos delictos que aly se fizerem e remetellas por treslado ao Ouvidor geral de Pernambuco..." 43 . Percebe-se uma imaginada reforma do território como objetiva intenção, plasmada na instituição de juízes ordinários racionalmente distribuídos pelo espaço geográfico dos sertões. Uma racionalidade que via o "vazio judicial" 44 como
39. Cf. Arquivo Histórico Ultramarino_Administração Central_ Conse 1 h o Ultramarino_Piauí, Cx. 2, D. 96.

40. Cf. Ibid.

41. Cf. Arquivo Histórico Ultramarino_Administração Central_ Consel ho Ultramarino_Piauí, Cx. 2, D. 96.

42. Ver Cf. F. A. Oliveira Martins (1944, p. 22).

43. Cf. Ernesto Ennes (1938, p. 350-351).

44. Cf. Joaquim Romero Magalhães (2011, p. 169). 
45. Ver Joaquim Romero Magalhães (2011, p. 170).

46. Cf. Anais da Biblioteca Nacional do Rio de Janeiro (1908, p. 343).

47. Ver Joaquim Romero Magalhães (2011, p. 149)

48. Cf. Arquivo Histórico Ultramarino_Administração Central_ Conse 1 ho Ultramarino_Pernambuco, Cx. 18, D. 1771.

49. Cf. Arquivo Histórico Ultramarino_Administração Central_ Conse 1 h o Ultramarino_Piauí, Cx. 1, D. 65. oposição à ordem pretendida pela Coroa. Joaquim Romero Magalhães ${ }^{45}$ observou que a desmontagem desse vazio se iniciou quando o Estado português decidiu criar os cargos de juiz ordinário onde o adensamento populacional justificasse, consolidando uma "rede de juízes" precisamente localizados em seus variados sertões, fossem em Rodelas, na ribeira do rio Piancó, no Ceará ou no curso do rio São Francisco.

A resposta ao requerimento do bispo e do governador veio por carta régia de 20 de janeiro de 1699. D. Pedro II ordenou a criação do cargo de juiz em cada freguesia "...que tenho mandado formar pelos ditos Certões...á similhança dos Juizes de vintenna, que ha n'este Reyno, o qual será um dos mais poderozos da terra; e para que este viva seguro fazendo o seu officio..." 46 . A sugestão de distribuir a cada cinco léguas um juiz não teve o sucesso esperado. A Coroa preferiu um quadro territorial mais amplo, o da freguesia ${ }^{47}$. Nessa citação há uma clara ideia reformadora e contraditória ao mesmo tempo. Embora Sua Majestade tenha se preocupado em reorganizar a sociedade dos "certões" oficializando os juízes nas paróquias, recomendava-se o cargo para os mais "poderosos" do lugar, quiçá por razões econômicas. Talvez a elite local não necessitasse dos pecúlios oriundos da Fazenda Real, sustentando-se por si nos trajetos feitos em dia de devassa. Poupavam-se os cofres régios fragilizados pela Reconquista (1640), pela queda do preço do açúcar e pela guerra contra os holandeses travada na parte Nordeste do Estado do Brasil. Não obstante, os mesmos homens poderosos poderiam ser aliados da Casa da Torre, da Casa da Ponte e de Domingos Afonso Mafrense, grupo de que outra carta régia datada do mesmo dia da anterior tentava reduzir o poder irrestrito no tocante às sesmarias irregularmente distribuídas:

...nam se povoarem os Certões delle por estarem dadas a duas ou três pessoas particulares que cultivão as terras que podem deichando as mais devolutas sem consentirem que pessoa alguma as povoe salvo $\mathrm{q} \cdot{ }^{\mathrm{m}}$ a sua vista as descobrir defender e thes pagar dizimo de foro por cada Citio cada hum anno... ${ }^{48}$

De fato, alguns desses juízes eram procuradores ou administradores das fazendas de gado desses homens, o que reforçava o seu controle sobre o território e o povo.

Nos sertões das capitanias do Norte e do Estado do Maranhão, a documentação relativa aos cargos de juiz de vintena ltambém chamados de espadanos ou pedâneos) e juiz ordinário em geral os confunde. Em vez de citar a nomeação de um vintenário para determinada freguesia, a Coroa ou algum ouvidor optava por um juiz ordinário e seu respectivo escrivão. José de Barros Coelho, ouvidor da comarca do Piauí, escreveu que havia dado "... aos juízes Pedanos o titulo de Juizes Ordinr. os com o conhecimento das causas dos crimes..." 49 . A localidade beneficiada com juiz e escrivão recebia o título de "julgado", e o corpus administrativo dos julgados dos sertões do Norte era bastante simples. Os juízes e 
escrivães tinham uma jurisdição territorial na qual exerceriam suas funções. Nalguns casos, a jurisdição coincidia com os contornos territoriais da freguesia, em acordo à normativa de 20 de janeiro de 1699. Em outros, geralmente nas povoações sem o status de paróquia, a circunscrição territorial era determinada pelos ouvidores e/ ou vereadores da vila a que o julgado estava subordinado. Os juízes recebiam um regimento pelo qual deveriam guiar suas práticas judiciárias. Por exemplo, na criação dos julgados de Salinas de Santo António de Pilão Arcado e Campo Largo, em 1753, as autoridades homologaram o Regimento que hão de observar os dous Juizes Ordinários e seus escrivães e meyrinhos dos Sítios das Salinas, e Campo Largo (...) no termo da criassão da nova Villa [Barra] a f.6 do devido Regimento do dito termo declarado que Sua Mag. efoy servido contribuir pella provisão que no fim deste mesmo requerimento vay copiada ${ }^{50}$.

A freguesia de Nossa Senhora da Vitória recebeu o seu juiz com seu respectivo escrivão após a emissão da resolução régia, pois segundo o inventário de 1711 das fazendas localizadas nas ribeiras dos rios Piauí e Canindé e herdadas pela Companhia de Jesus de Salvador, os padres Manuel da Costa e Matheus Francisco mencionaram o "...Juiz da terra com seu Escrivão..."51. Doravante, a repercussão da lei atingiu outras paróquias dos sertões de Rodelas e da Bahia. Atanázio Cerqueira Brandão solicitou o cargo de escrivão do juiz da freguesia de São Francisco das Chagas da Barra do Rio Grande do Sul, ". . .este oficio se criou de novo naquella freg. ${ }^{a}$ assim como outros semelh. es dos Certoins por rezolução de V. Mag. . de 20 de Janr. ${ }^{\circ}$ de 1699..."52. Até 1712, conhecem-se os julgados de Ararobá, Cabrobó, Barra, Água Fria e Piancó.

A autonomização da vila de Mocha e a criação da capitania e comarca do Piauí trouxeram outras representações àqueles sertões relacionadas à definição de suas circunscrições e à formação de sua rede urbana. $\bigcirc$ Piauí deslocava-se de Rodelas e da ribeira de batismo, ampliando-se a uma identidade territorial, cujas mudanças mais significativas foram vivenciadas simbólica e materialmente no ministério do marquês de Pombal.

A vila, a comarca, a capitania e as reformas de Antonio Marques Cardoso

As instruções passadas na carta régia de 20 de janeiro de 1699 foram importantes medidas para a regularização territorial do Piauí. As políticas de reforma levadas a cabo em Pernambuco foram estendidas ao Estado do Maranhão por carta régia de $\mathrm{O} 3$ de março de 1702, na qual os sesmeiros e donatários foram obrigados a apresentarem as devidas confirmações de terras no prazo de seis meses. Ao invés, haveria a privação das sesmarias, "...e eu [D. Pedro II] as poderei dar a quem for servido"53. O rei propunha assegurar a posse de um grande número de colonos que já haviam ocupado as terras, porém sem os títulos legais de concessão ${ }^{54}$. A partir dessa cronologia, o que se conhecia como sertões do Piauí anexava-se ao Estado do Maranhão. E o teor do discurso do documento deixava
50. Cf. Arquivo Histórico Ultramarino_Administração Central_ Conse 1 ho Ultramarino_Pernambuco, Cx. 152, D. 11015.

51. Cf. Arquivo Histórico Ultramarino_Administração Central_Consel ho Ultramarino_Piauí, Cx. 1, D. 15.

52. Cf. Arquivo Histórico Ultramarino_Administração Central_ Conselho Ultramarino_Alagoas, Cx. 1, D. 64 .

53. Cf. Anais da Biblioteca Nacional do Rio de Janeiro (1948, p. 212).

54. Ver Luiz Alberto Moniz Bandeira (2000, p. 248). 
55. Cf. Ver Arquivo Histórico Ultramarino_Administração Central_ Con s e 1 h o Ultramarino_Maranhão, Cx. 11, D. 1138.

56. Cf. Arquivo Histórico Ultramarino_Administração Central_ Consel ho Ultramarino_Maranhão, Cx. 11, D. 1138.

57. Cf. Ibid.

58. Ver Renata Malcher de Araujo (2013, p. 88-100).

59. Cf. Ibid. (p. 186).

60. Cf. Arquivo Histórico Ultramarino_Administração Central_Cons e $1 \mathrm{ho}$ Ultramarino_Maranhão, Cx. 11, D. 1138.

61. Cf. Ibid.

62. Cf. Anais da Biblioteca Nacional do Rio de Janeiro (1948, p. 105). claro os motivos da Coroa de vigiar os seus domínios e a vida que os animava. Dessa forma, imaginava-se enquadrar o território noutra representação, contrária aos interesses vigentes na Bahia e em Pernambuco.

Uma das propostas iniciais de reordenamento do espaço judiciário, requerido pelas autoridades do Maranhão para os sertões do Piauí, dizia respeito a instituir um juiz de fora ou ouvidor. O ouvidor-geral do Maranhão, Eusébio Capelli, em correição àquela parte da colônia no ano de 1711, executou devassas, procurou regularizar as finanças do cofre dos defuntos e ausentes e demarcou algumas sesmarias ${ }^{55}$. Naquela ocasião, os moradores solicitaram um juiz letrado, preferivelmente um ouvidor em vez de juiz de fora, "...porq' havendo juiz de fora fica suspensa a primr. ${ }^{a}$ e mais antiga forma de haver juizes nesta Capp. nia; o q' he contra a nobreza da rigallia della..." 56 .

Capelli enviou ao reino uma conta desaprovando a criação da ouvidoria ou o cargo de juiz de fora, "...porq. 'o não ha povoação alguma, em q' asistir, e p. ${ }^{\text {la }} \mathrm{gr} .{ }^{\text {de }}$ necessidade e falta $q^{\prime}$ faz p. $^{a}$ socego daquelles moradores só tem algum recurso na freguesia da Moxa, aonde asiste o Parroco e algumas pessoas mais ainda $q^{\prime}$ poucos, e assitem por obrigação tambem os Juizes..." 57 . Para o ouvidorgeral, o aspecto proto-urbano ${ }^{58}$ da freguesia de Nossa Senhora da Vitória e o seu respectivo julgado não correspondiam prerrogativas à formalização de uma comarca (também chamada de ouvidoria no Brasil colônia). Seria preciso atribuir àquele espaço um conjunto de povoações equacionado essencialmente por vilas e cidades, níveis hierárquicos responsáveis pela construção de territórios em escala alargada. Como sugere a interpretação de Renata Malcher de Araujo ${ }^{59}$ em recente estudo sobre a formalização da capitania de Mato Grosso, "as vilas são a arquitetura do território, as unidades de sua construção".

O diagnóstico de Capelli foi considerado pelo Conselho Ultramarino. O procurador da Coroa apresentou como "remédio" das desordens do Piauí a constituição duma república ordenada, "... porq' todos os seus habitantes herão curraleyros, que vivião cada hum na sua sorte de terra com seus gados..." 60 . Cabia a Sua Majestade a decisão final de criar uma vila "...naquelle lugar onde esta a Igreja...", e, somente assim, "... despois de estar fundada a villapello modo afferido, seria conveniente $q^{\prime} \bigvee$. Mag. ${ }^{d e}$ mandasse hum Ouvidor, como elles querem..." 61 .

Dom João V aprovou a resolução do Conselho Ultramarino em 30 de junho de 1712, convertendo a paróquia de Nossa Senhora da Vitória a vila, batizando-a de Mocha em referência ao riacho envolvente, "...com Senado da Camara, na qual haja dous Juizes (que já há) tres vereadores seus Almoteceis, e Escrivão da câmara e procurador tudo na forma da Ordenação..."62. A vila reorganizou o Piauí, repartindo-o em três instituições subordinadas aos principais centros de poder colonial: a instância judiciária esteve encabeçada pela Relação da Bahia, para onde os agravos e apelos eram remetidos; a administração do território era agenda do governador do Estado do Maranhão e, por fim, a dimensão religiosa permaneceu na diocese de Pernambuco até os primeiros anos da terceira década do século XVIII. A vila da Mocha foi especificamente implantada para ser 
a sede ou "cabeça" da comarca, tornando-se o polo político e administrativo ordenador de toda a população das fazendas e sítios, assim como dos índios congregados em aldeamentos missioneiros e convertidos em "filhos do rei".

A instalação efetiva da vila aconteceria em 26 de dezembro de 171763, seguida de projetos de reestruturação estimulados pelas autoridades locais em constante comunicação com os oficiais de Lisboa. Em dezembro de 1718, a capitania do Piauí foi criada como anexa a do Maranhão64. D. João V, por provisão de 1722, autonomizou a comarca e a provedoria, criando, por seu turno, "...o lugar de ouvidor-geral para a dita vila e capitania [...] unindo a ele a provedoria da fazenda real e dos defuntos e ausentes..." 65 . No reino, o bacharel António Marques Cardoso foi nomeado para ocupar o cargo de ouvidor, animando-o a peticionar as provisões necessárias para seu embarque ao Maranhão e viagem por terra aos sertões de sua jurisdição ${ }^{60}$.

Marques Cardoso propôs políticas de estruturação da ouvidoria desde a sua chegada, objetivando "... a conservação do d. . Certão e augmento da Fazenda Real..."67. A ideia por trás de "conservar" reveste-se de um duplo sentido - ético e utilitarista. A fundação de povoações oficializadas pela Coroa, em especial as vilas e as cidades, absorveu um discurso moral, no qual tudo aquilo que desviasse a ordem encarava-se como um "mal" passível de "remédio". Por isso, os textos oficiais utilizaram com certa frequência o verbo "remediar", no intuito de sanar os malefícios da desordem. Para a Coroa, seus funcionários e elites coloniais, os sertões do Brasil eram "doentios", seja pela alteridade figurada no índio bárbaro e barreira impeditiva da expansão colonial, seja pela violência e pela tensão vividas pela população na esfera social e fundiária. "Conservar" o Piauí de diferentes escalas - a comarca, a capitania e a vila - significava manter o "todo" territorial (como um corpo) sem dano, "observando o que pode ajudar"68 por experiências percebidas in situ ou por agendas emanadas do poder central metropolitano. Ainda se conservava o território visando o aumento pecuniário dos cofres régios por meio do cultivo e do florescimento da terra concedida segundo as dimensões legais.

controle dos povos nativos foi outra questão destacada nas correições do ouvidor. Como se sabe, o Piauí era habitado por milhares de índios, alguns deles contrários ao contato lusitano e à sua maneira de utilizar o território. Até a década dos anos 1770 foram registradas "guerras justas" e descimentos autorizados pela Coroa. Nesse caso, a metodologia encontrada por Marques Cardoso fundamentou-se na dimensão urbana, em especial na criação de outras vilas

...nas partes que achar com pessoas capazes de servirem aos cargos de Officiães das Cameras, e nas $\mathrm{d}$. as Villas as justiças $q^{\prime}$ forem necessárias, porque nesta forma começa a cresser a povoação; que unidas em partes; que fiquem prox. ${ }^{\text {as }}$ à habitaçam dos gentios, os intimide, e se facilita a communicação com o concurso das passagens, de que poderá rezultar concórdia, e sem haver contenda p. ${ }^{a}$ os expulsar, e parecer conveniente a sua conservaçam, por se augmentar a povoação com os mesmos naturães ${ }^{69}$.
63. Ver F. A. Pereira da Costa (1974, p. 82).

64. Ver Ibid. (p. 86).

65. Cf. Ibid. (p. 91).

66. Cf. Arquivo Histórico Ultramarino_Administração Central_ Conse $1 \mathrm{ho}$ Ultramarino_Piauí, Cx. 1, D. 17 .

67. Cf. Arquivo Histórico Ultramarino_Administração Central_Consel ho Ultramarino_Piauí, Cx. 1, D. 19.

68. Cf. Raphael Bluteau (1728, p. 477).

69. Cf. Arquivo Histórico Ultramarino_Administração Central. Conselho Ultramarino. Piauí, Cx. 1, D. 19. 
70. Ver Arquivo Histórico Ultramarino_Administração Central_ Conselho Ultramarino_Piauí, Cx. 1, D. 32.

71. Cf. Ibid.

72. Cf. Ibid.

73. Cf. Arquivo Histórico Ultramarino_Administração C e n tral_ Cons e 1 h o Ultramarino_Paraíba, Cx. 4, D. 310 .

74. Cf. Arquivo Histórico Ultramarino_Administração Central_ Conse $1 \mathrm{ho}$ Ultramarino_Piauí, Cx. 1, D. 26.

75. Cf. Arquivo Histórico Ultramarino_Administração Central_ Cons e $1 \mathrm{ho}$ Ultramarino_Maranhão, Cx. 29, D. 2978.
Por um lado, as vilas imaginadas seriam espaços de proteção àqueles índios sintonizados ao sistema de viver colonial, substanciado na administração da justiça pela câmara e na disciplina religiosa. Por outro, seriam agentes de repulsão daqueles avessos à cultura europeia, repelidos cada vez mais aos matos e caatingas. Os núcleos urbanos, assim, enquadrariam fronteiras externas e internas com contornos virtuais e objetivos, caso lograssem. Ademais, outro dado relativo à agência desempenhada pelas vilas merece relevo, visto que outros índios estariam motivados a transfigurar-se segundo as lógicas europeias. De acordo com o discurso de António Marques Cardoso, essa clivagem tiraria dos "naturais" a barbaridade e a rusticidade, trazendo-os ao seio de espaços tratados como civilizados e "conservadores", segundo o significado exposto anteriormente.

Em vez de vilas, optou-se por julgados. Os novos julgados foram situados em partes estratégicas da comarca. Parnaguá (ao sul), Piracuruca (ao norte) e Surubim (a oeste) foram as povoações convertidas a esse status em 1724: as duas primeiras implantadas nas extremidades do Piauí, cada uma distante cerca de 120 léguas de $\mathrm{Mocha}^{70}$. O oficial ainda recomendou a criação dos cargos de juiz e escrivão para a paróquia de Santo António do Gurguéia, na qual os conflitos entre índios e colonos desestabilizavam o cotidiano dos moradores daquela área ${ }^{71}$. Também se aventou o mesmo programa para a passagem da ribeira do Parnaíba "...p. ${ }^{a}$ se evitarem alguãs desordens, q' podem suceder com o concurso de homens de negócios $q^{\prime}$ de pres. ${ }^{\text {te }}$ o vão fazer ao Mar. ${ }^{a \circ}$ donde conduzem os panos de algodão com q' tractão neste Certão e fora delle ate dentro das Minnas..."72.

Cada uma dessas localidades apresentou uma especificidade, mobilizando Marques Cardoso a adotar um planejamento prévio que viesse a uniformizar a capitania para o bem comum dos povos. Ele pensou além. Seus projetos de reforma em macroescala buscavam extrapolar as fronteiras do Piauí daquela cronologia. $\bigcirc$ que estava em causa era o Piauí mais a colônia como um corpo racional e interligado. Isso parece razoável, porque, em 1724, o governador do Maranhão, João da Maia da Gama, expôs à Sua Majestade o seu apoio às resoluções tomadas pelo ouvidor do Piauí. Além de citar uma melhor distribuição da justiça ao longo da comarca, concentrada quase que exclusivamente no único concelho, Gama mencionou o exemplo do julgado de Piancó, localizado nos sertões da Paraíba e aprovado por resolução régia de 171073, cuja criação, durante sua administração como capitão-mor naquela capitania, procurou balancear as injustiças praticadas nas fazendas da ribeira dos rios Piranha e Piancó $^{74}$. O que talvez fosse uma opção para as especificidades de determinada comarca valia como modelo, alongando-se a outras circunscrições, inclusive de outro Estado como era o do Maranhão e Grão-Pará. Com efeito, anos mais tarde, outros três julgados foram oficializados no Maranhão: Aldeias Altas, São Bernardo da Parnaíba e Mearim ${ }^{75}$.

As reformas territoriais do Piauí abrangeram a dimensão religiosa por meio da criação de capelas e curatos. Em 1729, o bispo do Maranhão, António Troyano, deu parte à Coroa de sua jornada por quase toda a capitania, "...dando 
providencia a muitas couzas, como forão mandar erigir alguãs cappellas, nomeando para ellas cappellães, para os moradores que ficão em notáveis distancias, poderem receber mais promptamente os Sacram. ${ }^{\text {tos }} . . .76$. $\bigcirc$ prelado, em associação com o ouvidor, sacralizou novos lugares para poder exercer a sua jurisdição. As capelas e freguesias, metaforicamente, eram vistas como espaços transfiguradores de "feras indomitas" em gente "domada, e domesticada, q' tudo já abração com suma obediência..."77.

Entretanto, o que, principalmente, estava em jogo dizia respeito ao controle fiscal dos dízimos ilegalmente coletados pela diocese de Pernambuco. De fato, tanto Parnaguá como Piracuruca foram alvos das ações do bispo, haja vista que os padres das freguesias da Barra do Rio Grande do Sul e do Acaracú, situadas em Pernambuco e Ceará respectivamente, cobravam os dízimos dos moradores das ribeiras da capitania do Piauí, remetendo-os a Pernambuco. António Troyano chamou a atenção de D. João $V$ para o fato de que aqueles curatos se situavam em sua diocese. Por esse motivo,

para o districto do Paránouguá trouxe em minha companhia sacerdote para Parochodelle, por se poder fazer já hoje hum grande curato [...] porq' com elle poderei obviar alguãdamnoza contradição, e sem alguã exerço a jurisdição q' V. Mag. ${ }^{\text {de }}$ me manda tomar a meu cargo [...] também o Parocho da freg. ${ }^{a}$ ou curato de N. ${ }^{a}$ Sr. ${ }^{a}$ do Carmo de Piracuruca [...] me requer com instancia, que volte aquellas partes para que com minha presença se assentar na verdadeira devisão... ${ }^{78}$

Quanto à dimensão intraurbana de Mocha, certas medidas de melhoria espacial e administrativa foram iniciadas na jurisdição de António Marques Cardoso. No entanto, algumas delas efetivaram-se décadas mais tarde, durante o ministério de Sebastião José de Carvalho e Mello. A construção de novas sedes para a casa de câmara e cadeia e a fundação do colégio e hospício ${ }^{79}$ dos jesuítas, por exemplo, renderam acordos e atritos entre os agentes envolvidos nos processos.

A casa de câmara, a cadeia e o pelourinho eram os símbolos materiais erguidos nos espaços urbanos das vilas a exprimir a autonomia administrativa do concelho. Nas câmaras, reuniam-se os vereadores, juízes ordinários, escrivães, meirinhos e almotacés para acordar os temas das vereações, executar as devassas, punir os delinquentes e fixar os pesos e as medidas. Na ausência desses edifícios, as residências de juízes ou casas alugadas serviam como sede da câmara ou prisão. Em Mocha, nas duas primeiras décadas do século XVIII, tais arquiteturas oficiais não existiram. Como testemunhado pelo ouvidor António Marques Cardoso, "...ate o tempo, em q' entrey neste lugar [...] tractey de introduzir cadea em huãs casas em que morava hum official de justiça..." 80 . Sobre esses aspectos, os trabalhos do ouvidor revelaram-se pragmáticos, matizados em exercícios pedagógicos quando tratou de "...capacitar os officiaes da Camara que devia o povo concorrer para essa obra [dos prédios oficiais] por ser assi[m] obrigado..."81. A "república" imaginada do Piauí expandia seus contornos aos povos, processando um conjunto de resoluções a resultar no bem comum almejado. A casa de câmara
76. Cf. Arquivo Histórico Ultramarino_Administração Central_Conse 1 ho Ultramarino_Piauí, Cx. 1, D. 45.

77. Cf. Ibid

78. Cf. Ibid

79. De acordo com Raphael Bluteau, um "hospício" seria uma espécie de convento pequeno de alguma família religiosa, em que acomodam os seus confrades quando estão de passagem pelo lugar. Cf. Raphael Bluteau (1728, p. 64).

80. Cf. Arquivo Histórico Ultramarino_Administração Central_Consel ho Ultramarino_Piauí, Cx. 1, D. 35.

81. Cf. Ibid.. 
82. Cf. FALLA, que derigio a Assemble'a Legislativa do Piauhy...(1835, p. 08).

83. Ver Fania Fridman (1999, p. 15). e a cadeia, independentes como construções, expressariam visualmente a experiência desses anseios morais. Ao que tudo indica, a conclusão das obras efetivou-se ainda na primeira metade do século XVIII. Não se tem a data precisa dessas operações, assim como os documentos fornecem poucas pistas por não seguirem uma sequência temporal lógica. Mesmo assim, os melhoramentos estruturais e decorativos da sede da câmara seriam assuntos recorrentes dos vereadores e outras autoridades até os primeiros decênios do Novecentos, quando a Junta Governativa do Piauí contratou o empreiteiro Pedro Cronemberger para concluir os reparos do edifício ${ }^{82}$ (Figura 02).

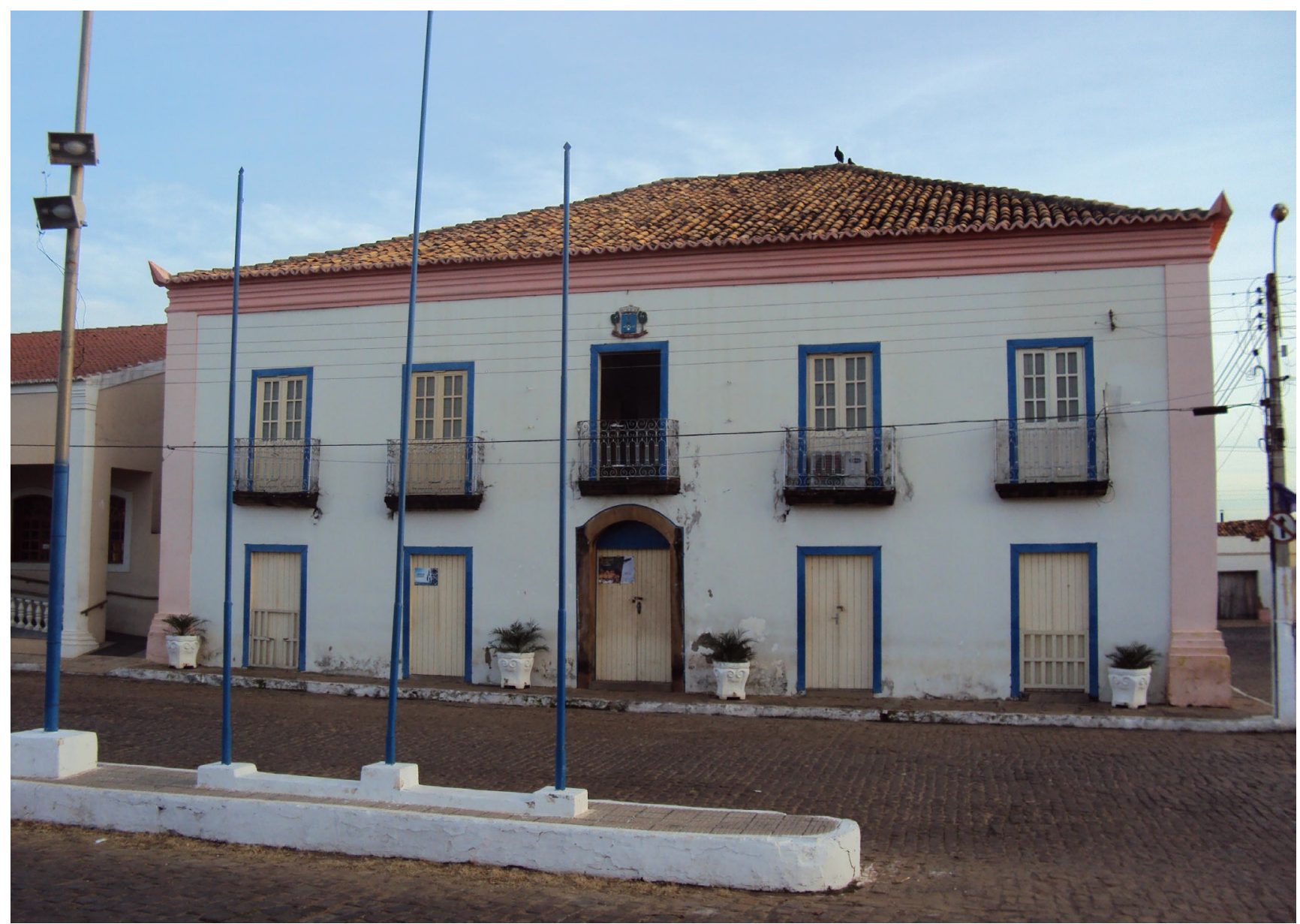

Figura 2 - Casa de câmara e cadeia de Oeiras do Piauí. Foło do autor, abril de 2010.

Outras arquiteturas se destacaram na paisagem urbana de Mocha, dinamizando as transformações materiais da vila fora do eixo da praça da igreja matriz, previamente dimensionada no ato da criação da paróquia. Os novos elementos arquitetônicos assumiram o papel reordenador de determinadas zonas da vila, culminando na segregação dos espaços por uso e classe social ${ }^{83}$. $\bigcirc$ hospício e colégio dos jesuítas foi um desses equipamentos incluídos na paisagem 
antes de 1750. Sua edificação envolveu agentes sociais já atuantes na formação original da vila, como o vigário Thomé de Carvalho e Silva e criadores de gado residentes em seu termo. O sacerdote ofertou "...doze mil cruzados e huã fazenda de gado..." 84 . Reuniu-se um montante de 46 mil réis para a obra, ofertados por João Campello da Fonseca $(10$ mil réis), Hylário Ribeiro de Carvalho (20 mil réis) e Maria da Encarnassão (16 mil réis) ${ }^{85}$.

Em 20 de abril de 1733, D. João V concedeu a licença ao vigário para fundar o hospício e colégio da Companhia de Jesus. Nesse ínterim, auxiliou o projeto com 3 mil cruzados ${ }^{86}$, com parte desse pecúlio destinada ao mestre pedreiro Domingos Dias da Costa, residente da vila e empreiteiro do plano. Segundo os padres jesuítas instalados no núcleo para tramitar os processos de construção do hospício, o partido arquitetônico, ou como se usava no período colonial, a fábrica do templo teria...

... O tamanho da igreja matriz desta Villa com sua Sacristia por detrás do Altar-mor como se costuma nos Colégios dos dittos padres. Tendo também o dittoHospicio de huma parte da ditta igreja humacoadra de Sobrados para cubícullos por sima com seu salam de hospedes e por baicho oficina deste... ${ }^{87}$.

Verifica-se uma prática ou tradição projetual jesuítica. Na opinião do arquiteto Lúcio Costa, o programa dos colégios, conventos e hospícios da Ordem contou em dispor vários corpos da edificação em "quadra", estruturando um pátio para a convivência dos religiosos ${ }^{88}$. A igreja alinhada ao cubículo contíguo resultaria numa fachada de único plano, uma linha horizontal harmônica. Os jesuítas, além de serem sensíveis à forma da obra, tinham o cuidado com sua localização, imprimindo um caráter funcional no núcleo urbano ao qual era erguido ${ }^{89}$. Pressupõe-se que houve um estudo prévio do lugar onde se estabeleceria a construção. Para não competir espacialmente com a igreja matriz, elegeu-se uma área mais afastada, após o riacho Pouca Vergonha. Trata-se de um sítio mais elevado que o terreno da matriz, o cume de um pequeno promontório90.

hospício e colégio dos jesuítas desencadeou a expansão urbana para o eixo sul da vila, urbanizando uma área afastada da praça central. Por volta de 1762, esse espaço abrigou uma população pobre branca, alguns escravos e negros forros. A ligação entre os dois polos - largo da igreja matriz e vizinhanças da nova edificação jesuítica - era feita por uma pequena ponte de longarinas de madeira sobre colunas de cantaria91. Expulsos os inacianos do Brasil em 1759, a ordem do Rosário dos Homens Pretos obteve licença para utilizar o templo em seus ofícios religiosos. Por volta de 1818, os viajantes Spix e Martius narraram os aspectos funcionais do "cubículo" que servia de moradia aos padres: "... atualmente casa do vigário, o qual tem autorização do bispo do Maranhão para exercer certas funções..."92. Já na óptica do médico e naturalista inglês George Gardner, que havia percorrido os sertões da província do Piauí em 1838, a construção era "... um grande e belo edifício, ora em ruínas..."93 (Figuras 03 e 04).
84. Cf. Arquivo Histórico Ultramarino_Administração Central_Conse $1 \mathrm{ho}$ Ultramarino_Piauí, Cx. 1, D. 75 .

85. Cf. Ibid.

86. Cf. Ibid.

87. Cf. Ibid

88. Ver Lúcio Costa (1941, p. 27)

89. Ver Fania Fridman (1999, p. 16).

90. Ver Esdras Arraes (2014, p. 95).

91. Ver Murilo Cunha Ferreira (2010, p. 62).

92. Cf. Spix, Martius (1938, p. 422).

93. Cf. George Gardner (1975, p. 125). 


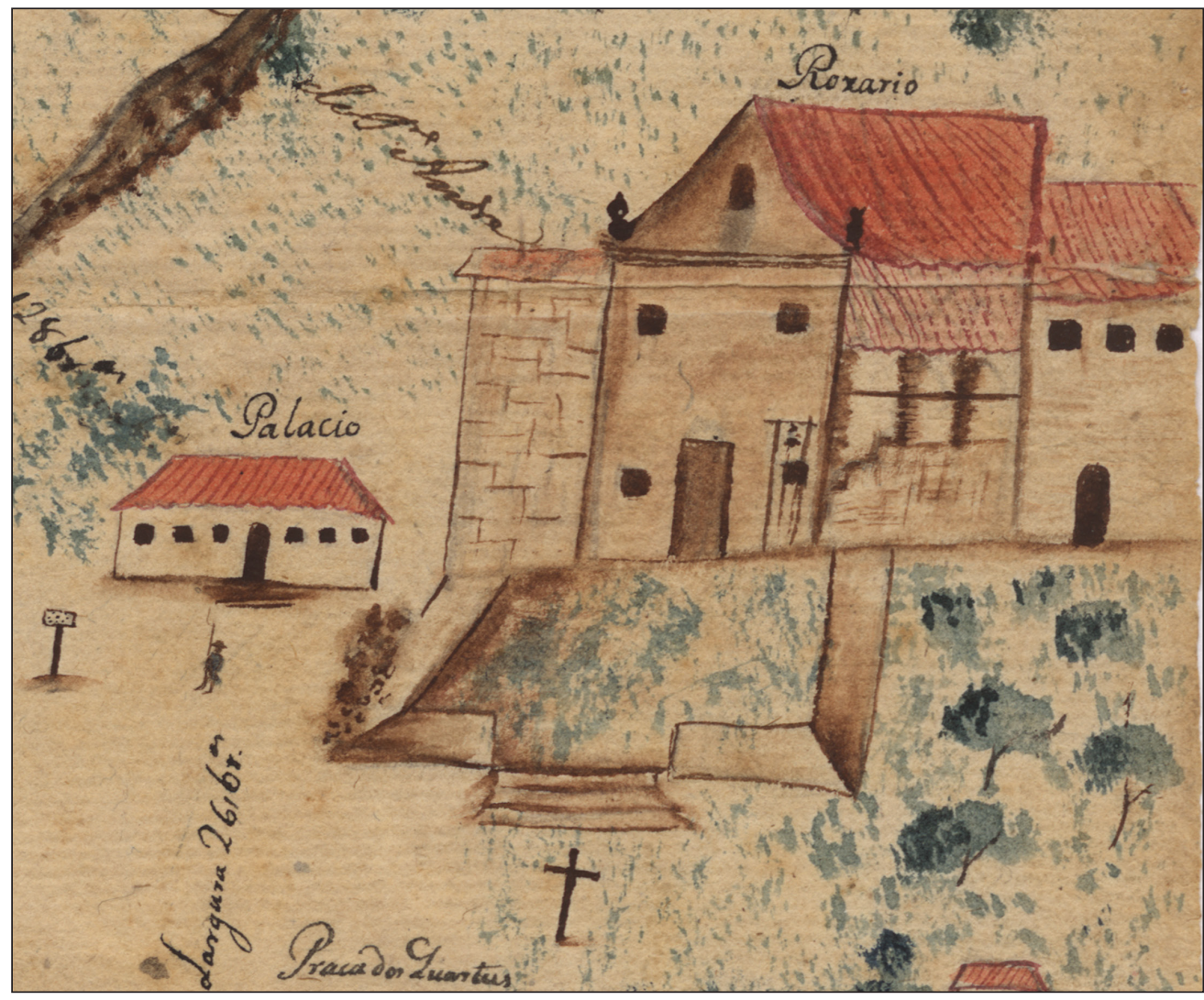

Figura 03 - Hospício e colégio dos jesuítas da vila da Mocha construído por volta de 1732 . Detalhe do mapa Oeyras do Piauhi. Original da Biblioteca Nacional de Portugal, Lisboa. Imagem de domínio público.

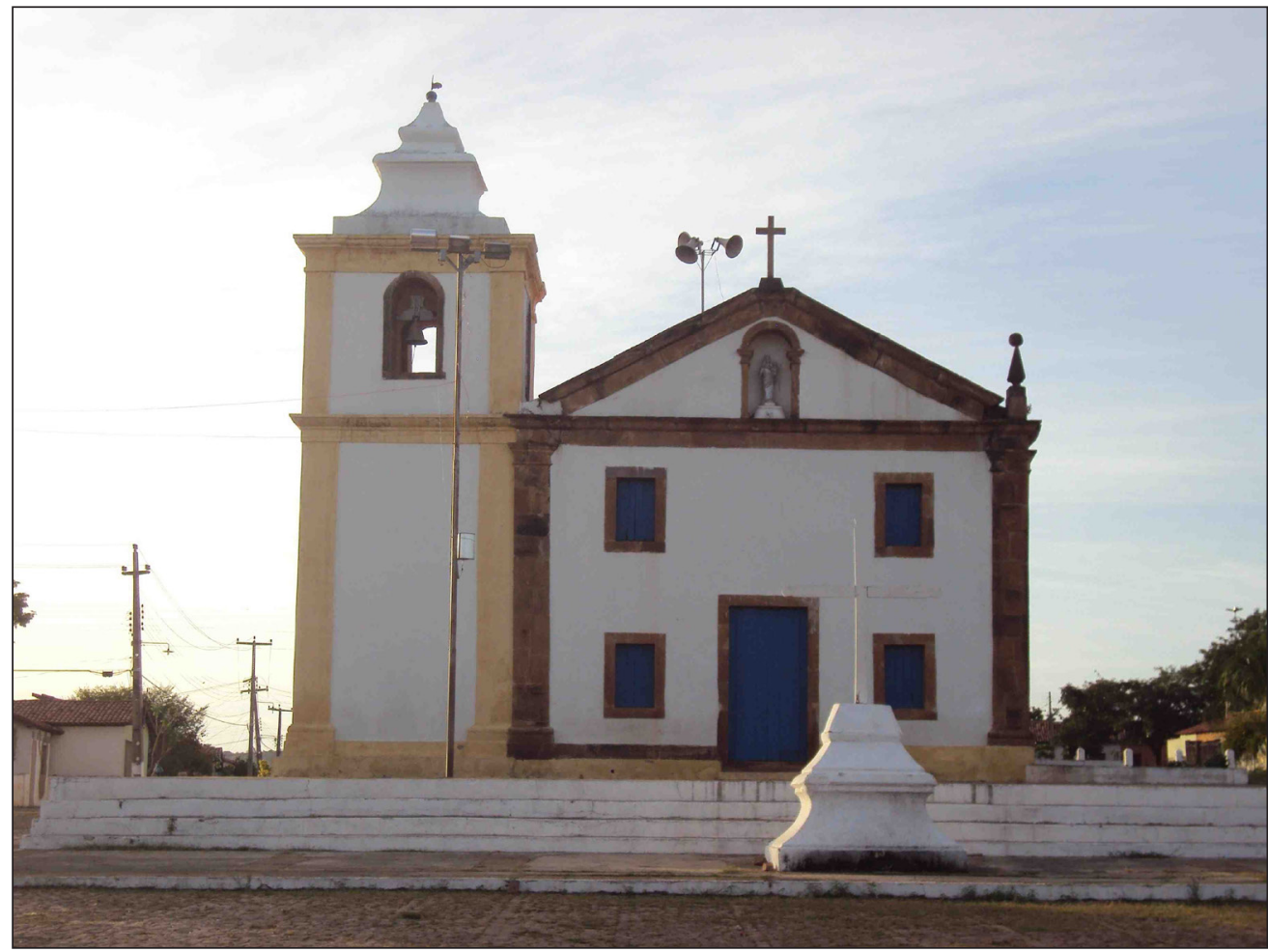

Figura 04 - Atual igreja do Rosário. Foto do autor, abril de 2010. 
Os resultados das políticas de urbanização de Antônio Marques Cardoso permaneceram praticamente os mesmos até a segunda metade do século XVIII, quando novos projetos foram implementados pela Coroa, por Francisco Xavier de Mendonça Furtado, pelo marquês de Pombal e pelas autoridades régias designadas ao Piauí. Entre os anos 1740 e 1757, as modificações articuladas na rede de povoações do território ocorreram no nível eclesiástico. O vice-vigário geral da diocese do Maranhão, João Rodrigues Covete, informou a criação de duas novas paróquias por resolução régia de 29 de maio de 1740, passada pela Mesa de Consciência e Ordens: "...huã na Catinguinha e outra no Gorogueia..."94. De modo que naquele recorte temporal, a capitania e a comarca do Piauí estiveram estruturadas por uma única vila (Mocha), três julgados (Piracuruca, Surubim e Parnaguá) e sete freguesias (Nossa Senhora da Vitória, Nossa Senhora do Carmo de Piracuruca, Santo António do Surubim, Nossa Senhora do Desterro do Rancho do Prato, Nossa Senhora da Conceição dos Aroazes, Santo António do Gurguéia e Nossa Senhora do Livramento de Parnaguá). Os manuscritos não informam se os três aldeamentos missioneiros estabelecidos pelo padre Thomé de Carvalho e Silva décadas antes progrediram a ponto de congregar um número de vizinhos capaz de implementar uma freguesia ou outro aglomerado de diferente perfil. Ao contrário, tudo indica a descontinuidade, pois foram criados três "lugares de índios"95, em 1772, a fim de civilizar os ameríndios segundo a legislação indigenista vigente.

O prenúncio de reformas mais profundas no Piauí apareceu no ofício de 18 de outubro de 1756 do agora bispo do Maranhão, João Rodrigues Covete, encaminhado ao secretário de Estado da Marinha e Ultramar, Tomé Joaquim da Costa Corte Real, acerca de descrições minuciosas dos lugares, povoações e freguesias da diocese, dando conta

....das distancias que ha [de] hum a outros [lugares], com seus nomes, declarando tambem os Rios q' pellas ditas Povoaçoens passão, os nomes q' se denominão, se são navegáveis e os seus nascimentos, as legoas, e os dias de jornadas q' ha de hum a outro, declarando-se tambem as pessoas que ha de comunhão nas suas Freguesias, e Capellas anexas a ellas ${ }^{90}$.

No ano seguinte, essa recomendação foi passada ao Estado do Brasil. conde dos Arcos coordenou as operações, ordenando aos ouvidores das respectivas comarcas a execução do "...que se determina..."97.

Além dos textos enviados pelos párocos das freguesias arrolando caminhos reais (públicos), currais, fazendas, capelas filiais, elementos hidrográficos e orográficos da paisagem e demográficos de suas circunscrições eclesiásticas, a Coroa retomou as questões envolvendo a regularização das sesmarias. Em 20 de março de 1755, D. José I assinou uma provisão enviada ao governador do Maranhão, Gonçalo Pereira Lobato de Sousa, designando o ouvidor do Piauí, José Marques da Fonseca Castelo Branco, "...para hir pessoalmente fazer as Demarcaçoens [que] comprehende geralmente todas as sesmarias; porem
94. Cf. Arquivo Histórico Ultramarino_Administração Central_Conse 1 ho Ultramarino_Piauí, Cx. 3, D. 185.

95. Jaicós, São João de Sende e São Gonçalo do Amarante.

96. Cf. Arquivo Histórico Ultramarino_Administração Central_ Consel ho Ultramarino_Maranhão, Cx. 37, D. 3671.

97. Cf. Arquivo Histórico Ultramarino_Administração Central_ Consel ho Ultramarino_Bahia, Cx. 13, D. 2447. 
98. Cf. Arquivo Histórico Ultramarino_Administração Central_ Conselho Ultramarino_Piauí, Cx. 5, D. 342.

99. Apud Renata Malcher de Araujo (2011, p. 06-07).

100. Ver F. A. Pereira da Costa (1974, p.128). attendendo algumas razoens que me foram prezentes. Hey por bem declarar que quando não possa hir pessoalmente escolha hum homem de inteligência e providade..."98. As descrições das freguesias e as demarcações das sesmarias atrelavam-se a um objetivo reordenador, clarificado num amplo sistema de medidas sócioterritoriais plasmado na racionalidade ilustrada em voga no Setecentos, no qual a ordem - das gentes, das terras e das povoações - figurava-se como base metodológica.

As autoridades nomeadas a executar as demarcações, como o desembargador Francisco Marcelino de Gouveia, o governador João Pereira Caldas e o engenheiro militar Henrique António Galuzzi aderiram ao método. Como veremos, esses agentes cumpriram uma importante agenda política a culminar numa nova representação do Piauí, relativa à sua autonomização como capitania independente da do Maranhão e na transformação da rede urbana, fundamentada na promoção de hierarquias de diferentes níveis, destacando-se a promoção da vila da Mocha à qualidade de cidade. Os sertões do Piauí que se fizeram e se pretendiam, apresentados em discurso e imagem (mapa) desses funcionários régios, condiz, em alguns aspectos, à complexidade socioeconômica e cultural dos outros sertões contíguos, aqueles das capitanias da Bahia e Pernambuco, por exemplo.

Em 1755, Francisco Xavier de Mendonça Furtado havia pensado em enviar ao Piauí o ouvidor geral do Pará, João da Cruz Dinis Pinheiro, para executar um levantamento e a reorganização hierárquica do território. Recomendava-se

...um exacto e individual plano do sobredito territorio, e as suas divisões, interpondo à vista dele o vosso parecer sobre a necessidade, que considerardes, ou não considerardes, em separar o mesmo território em duas ouvidorias, para serem mais fáceis as correições que nele se devem fazer; sobre as alfandegas, ou lugares, que vos parecer mais dignos de serem erigidos em vila; sobre os limites, que se hão de assinalar ao termo de cada uma delas; sobre as paroquias, e casas de instrução espiritual, que nas mesmas vilas de devem estabelecer...99.

A execução dessas recomendações não se concretizou naquela altura, tendo esperado até 1758, quando o desembargador Francisco Marcelino de Gouveia liderou a comissão das "...g. des Dermarcaçoens do Piauhy".

Por carta régia de 22 de julho de 1758, o desembargador Gouveia recebeu ordens de $\mathrm{D}$. José I a fim de dar início aos trabalhos de conhecimento territorial e levantamento da população residente na vila da Mocha e seu termo, nas paróquias, fazendas de gado e sítios ${ }^{100}$. $O$ périplo das autoridades por todo - Piauí rendeu uma valiosa documentação, apresentando-o como um ponto de inflexão entre o velho paradigma de um território plasmado no vazio e na inércia social para outro devidamente ocupado, transformado e dinâmico.

Os entraves oriundos da distribuição de sesmarias retornavam como um dos tópicos das missivas remetidas da vila da Mocha a Belém ou a Lisboa. Numa carta a Francisco Xavier de Mendonça Furtado, Marcelino de Gouveia apontava as razões da desordem parcialmente remediadas pelas ordens régias anteriores. 
Segundo o desembargador, os "embaraços" em que o Piauí se encontrava originavam-se da Casa da Torre e da Companhia de Jesus. Os Dias d'Ávila eram coniventes às injustiças e violências executadas por seus procuradores aos rendeiros "...vexados dos poderosos, não chegão a queixarce da violencia com que tem sido opermidos..." ${ }^{101}$. Quanto aos jesuítas, "...encherá vm' infinitos factos, porque thes conste as extorções que tem praticado, e as violencias que tem padecido esses mizeraveis moradores..." 102 . Mudavam-se apenas os atores, porque as atuações eram idênticas, relacionadas ao universo do poder e da violência.

Para os oficiais régios, a autonomização do governo do Piauí aparentava a solução mais aceitável. Também seria outra maneira de vigiar a Companhia de Jesus, onde os contornos da capitania a serem definidos na comissão demarcatória e simbolicamente representariam uma "imensa fortaleza", pois "e ao muito q" importa nas presentes circunstancias fortificarnos nos centros dos Certoens do Brazil, depois que se manifestou, q' por elles pertendião arruinar, e dominar aquelle Estado os Religiozos Jesuítas" ${ }^{\prime 03}$. $\bigcirc$ discurso direcionou-se também a questões econômicas, relacionando o governo autônomo a um possível aumento pecuniário dos moradores e da Fazenda Real, derivado da circulação comercial interna e do abastecimento entre capitanias de gado, carne e couro, produtos mercantis nos quais o Piauí especializou-se ${ }^{104}$.

Isso posto, em 29 de junho de 1758, D. José I oficializou a capitania, renomeada em sua honra como São José do Piauí ${ }^{105}$. João Pereira Caldas foi aprovado ao cargo de governador, e, desde sua chegada à vila da Mocha, esteve interessado em cumprir os desígnios de Sua Majestade. Realizou consideráveis balanços sociais, econômicos e territoriais junto com Francisco Marcelino de Gouveia e com o ouvidor Luís José Duarte Freire durante as demarcações da capitania. Numa dessas análises, Pereira Caldas relacionou a "ruína" do Piauí, como era esperado, ao controle fundiário da Companhia de Jesus, cujos produtos de suas 35 fazendas eram comercializados na Bahia e em Pernambuco, "...ficando apenas nesta capitania os limitados interesses dos vaqueiros e feitores..." 106 . Ele percebia a longa distância que separava a vila do mar como bloqueio ao desenvolvimento de todo o território. Por isso, a articulação de uma povoação oficial na costa atlântica com os sertões reduziria o percurso dos mercadores de gado, que eram quase obrigados a se deslocarem para outros centros da colônia, distantes meses dos currais de criação. $\bigcirc$ porto e a vila imaginados por Pereira Caldas, articulados num amplo sistema de comunicação - terrestre, fluvial e marítimo - seriam um dos meios de movimentar o "capital" internamente para a prosperidade da população local ${ }^{107}$.

Os trabalhos de reforma urbana empreendidos em São José do Piauí formavam parte do expediente das viagens de demarcação territorial. $\bigcirc$ desembargador Francisco Marcelino de Gouveia percebia a necessidade "... de se separar em duas a ouvidoria desta Comarca para serem nellas mais fáceis as correiçoins sobre os lugares que julgassem mais dignos de serem em $V$ as erigidos sobre os termos que os mesmos se [h]avia dar..." ${ }^{108}$. Segundo Renata Araujo 109, a criação de concelhos era pensada no âmbito do controle sobre a distribuição das
101. Cf. Arquivo Histórico Ultramarino_Administração Central_ Conse 1 h o Ultramarino_Piauí, Cx. 5, D. 365.

102. Cf. REGISTRO das cartas em geral das duas capitanias do Pará e Rio Negro, que escreve o Ill. ${ }^{\mathrm{mo}} \mathrm{e}$ Ex. ${ }^{\text {mo }}$ Sr. Francisco Xavier de Mendonça Furtado, Governador e Capitão General do Estado do Grão Pará e Maranhão. Correspondencia official (1754-1758). Colecção Pombalina. Biblioteca Nacional de Portugal.

103. Cf. Arquivo Histórico Ultramarino_Administração Central_Consel ho Ultramarino_Piauí, Cx. 5, D. 359.

104. Cf. Ibid..

105. Ver F. A. Pereira da Costa (1974, p.129).

106. Cf. Arquivo Histórico Ultramarino_Administração C e n t ral_ Consel ho Ultramarino_Piauí, Cx. 6, D. 378.

107. Cf. Ibid.

108. Cf. Arquivo Histórico Ultramarino_Administração Central_Conse $1 \mathrm{ho}$ Ultramarino_Piauí, Cx. 6, D. 395.

109. Ver Renata Malcher de Araujo (2011, p. 07). 
110. Cf. Arquivo Histórico Ultramarino_Administração Central_Cons el ho Ultramarino_Piauí, Cx. 6, D. 395.

111. Cf. Arquivo Histórico Ultramarino_Administração Central_ Conselho Ultramarino_Piauí, Cx. 6, D. 395.

112. Cf. Ibid.

113. Cf. Ibid. sesmarias e da resolução das tensões sociais latentes, sem esquecer que o fracionamento da comarca em duas ouvidorias visava a redistribuição das instâncias jurídicas e dos seus agentes, minimizando os conflitos e melhorando os rendimentos da Fazenda Real. Na ótica do desembargador e, de reboque, de João Pereira Caldas, a "dignidade" das povoações a serem beneficiadas com o predicamento de vila decorria das experiências sentidas in situ. Deixou-se claro que seria impróprio qualquer arbítrio sem "...ir pessoalm. te examinando nesta forma as Povoaçoins Citios e lugares de toda a Capitania, dando princípio a esta laboriosa peregrinação em os primeyros dias do mes de Julho do anno proximo passado [1759]..."110.

Não houve julgamento a priori sobre quais arraiais deveriam enquadrar - novo paradigma urbano do Piauí. Antes, o pragmatismo das autoridades, valendo-se do empirismo proporcionado pela observação direta do território, mostrava-se como metodologia em que as povoações "dignas" receberiam a autonomização administrativa. De fato, além dos tênues aglomerados humanos dispostos ao longo das ribeiras, Marcelino de Gouveia descreveu brevemente cada freguesia, arrolando o número de pessoas de desobrigas, as fazendas, alguns aspectos materiais e estéticos das igrejas paroquiais, a quantidade de moradias reunidas nas proximidades do templo católico e se havia homens capazes de ocupar os ofícios camarários. Das paróquias avaliadas, Nossa Senhora do Livramento do Parnaguá e Santo António do Surubim ajustavam-se ao conceito de "dignidade" do desembargador. As demais foram julgadas impróprias diante da fragilidade material da comunidade, apresentando igrejas construídas em taipa e implantadas em "lugares desagradáveis".

Parnaguá e Surubim, ambas julgados, tiveram outra representação. A primeira, "...que he freguesia decentemente preparada com asistencia do S. mo Sacramento, e com renda destinada, e estabelecida para sua perpetua existencia..." 111 , receberia o título tanto pela "prosperidade" dos habitantes do seu termo, como pela sua estratégica posição, "...porque está em a estrada que vay para as terras novas, ou novamente descubertas em a Comarca de Villa Boa de Goyas e promete o lugar da sua existencia, que a elle se venhão buscar gados, e os mais viveres necessarios para a subsistencia das pessoas que estiverem em as dittas terras novas..." 112 . Na realidade, a perspectiva reformista do desembargador expandia as fronteiras do Piauí para além daquela que estava a esboçar nas demarcações. Previa-se um dinâmico contato comercial entre capitanias vizinhas, ou melhor, entre as sociedades que as estruturavam. A comunicação era um fato existencial do território e daquela população residente em sertões distantes das principais cidades. Além disso, a vila pretendida para Parnaguá agiria como "sentinela" fiscal e administrativa de zonas indômitas, controlando possíveis descaminhos do ouro, comuns naquela área fronteiriça. A sua localização nas proximidades de uma estrada potencializava a sua autonomização. Quanto a Surubim, a materialidade do arraial apareceu como a razão de sua elevação hierárquica: " ...tem ao pres. ${ }^{e}$ a Povoação trinta e sete fogos e lgreja também com bastante decencia..." 113. Em termos geográficos, a fundação das duas vilas, uma 
a norte e outra a sul da capitania, equacionaria uma tríade capaz de controlar e reordenar áreas anteriormente administradas exclusivamente por Mocha, distribuindo equitativamente os respectivos termos, a aplicação da justiça aos moradores e fracionando a capitania em três partes de dimensões aproximadas. Transparece no discurso oficial uma clara ideia de urbanizar, autonomizando concelhos a fim de reformar o território e fixar a população das fazendas e dos sítios em povoações aprovadas pelo rei. Isso conferiu ao Piauí, segundo Araujo ${ }^{114}$, um espaço de experiências e adaptação de paradigmas.

As freguesias inaptas a receber o pelourinho e a casa de câmara não foram deixadas de lado. Francisco Marcelino de Gouveia direcionou à Coroa outro projeto para as quatro paróquias. Mais uma vez a opção por julgado convergia à realidade social dos assentamentos, pois fazia "...indispensavel a minha obrigação procurar todos os meios p. ${ }^{a}$ as partes milhorarem de fortuna, não só ficando sem a opressão q esprementão quando se atropelava a justissa..." ${ }^{115}$. No manuscrito inédito Direção que andem seguir os Juizes das Povoaçoins abaycho declaradas os seus respectivos Julgados, o desembargador redigiu à Vossa Majestade as justificativas adotadas para converter as freguesias em julgados. Trata-se de um documento primoroso no qual o oficial régio, representação simbólica da ilustração europeia, decidiu de maneira pragmática regularizar o sistema judiciário da capitania em macroescala. Declaravam-se as obrigações dos juízes ordinários, escrivães e meirinhos, assinalando-os as suas jurisdições, normalmente confundindo-se com a circunscrição eclesiástica da paróquia.

Temos, portanto, a urbanização imaginada pelos funcionários régios para São José do Piauí após a longa jornada de demarcação, experimentando espaços, lugares, paisagens e pessoas. Processos matizados numa rede urbana hierarquizada por povoações de distintos níveis: três vilas Mocha, Surubim e Parnaguá) e quatro julgados (Buriti dos Lopes, Rancho do Prato, Cotinguinha e Gurguéia). Sem embargo, as demarcações do Piauí requeriam uma imagem que representasse a objetificação do método proposto pelas autoridades a fim de corroborar com as experiências apreendidas. $\bigcirc$ trabalho do engenheiro militar e cartógrafo, Henrique António Galuzzi, deu existência à capitania, no papel, cujos limites geográficos foram definidos por meio de traços e símbolos cartográficos.

Galuzzi já estava na vila da Mocha em setembro de 1759, antes de partir para sua viagem de inspeção, percorrendo ribeiras e caminhos, atravessando bosques de carnaúbas, e testemunhou a dificuldade de se viver em ambientes áridos. Em novembro do mesmo ano, o dr. Francisco Marcelino de Gouveia informava a Tomé Joaquim Corte Real sobre as vistorias realizadas nas freguesias junto com o engenheiro, "...destinado a tirar hum plano exacto e individual do territorio da mesma [capitania]..." 116 . Antes de sua partida, porém, Galuzzi solicitou ao padre Ignacio Samartoni os dados astronômicos sobre o primeiro satélite de Júpiter, visando determinar as longitudes necessárias para a confecção do mapa ${ }^{117}$. A cartografia auxiliaria o método empregado pelas autoridades na construção do Piauí, além de ser um instrumento fundamental às políticas de urbanização que
114. Ver Renata Malcher de Araujo (2011, p. 07).

115. Cf. Arquivo Histórico Ultramarino_Administração Central_Conse 1 h o Ultramarino_Piauí, Cx. 6, D. 389.

116. Cf. Ibid.

117. Ver Renata Malcher de Araujo (2011, p. 07). 
118. Cf. Arquivo Histórico Ultramarino_Administração Central_ Consel ho Ultramarino_Piauí, Cx. 7, D. 435.

119. Cf. Arquivo Histórico Ultramarino_Administração Central Cons e 1 ho Ultramarino_Piauí, Cx. 7, D. 436.

120. Cf. Arquivo Histórico Ultramarino_Administração Central Cons el ho Ultramarino_Piauí, Cx. 7, D. 437.

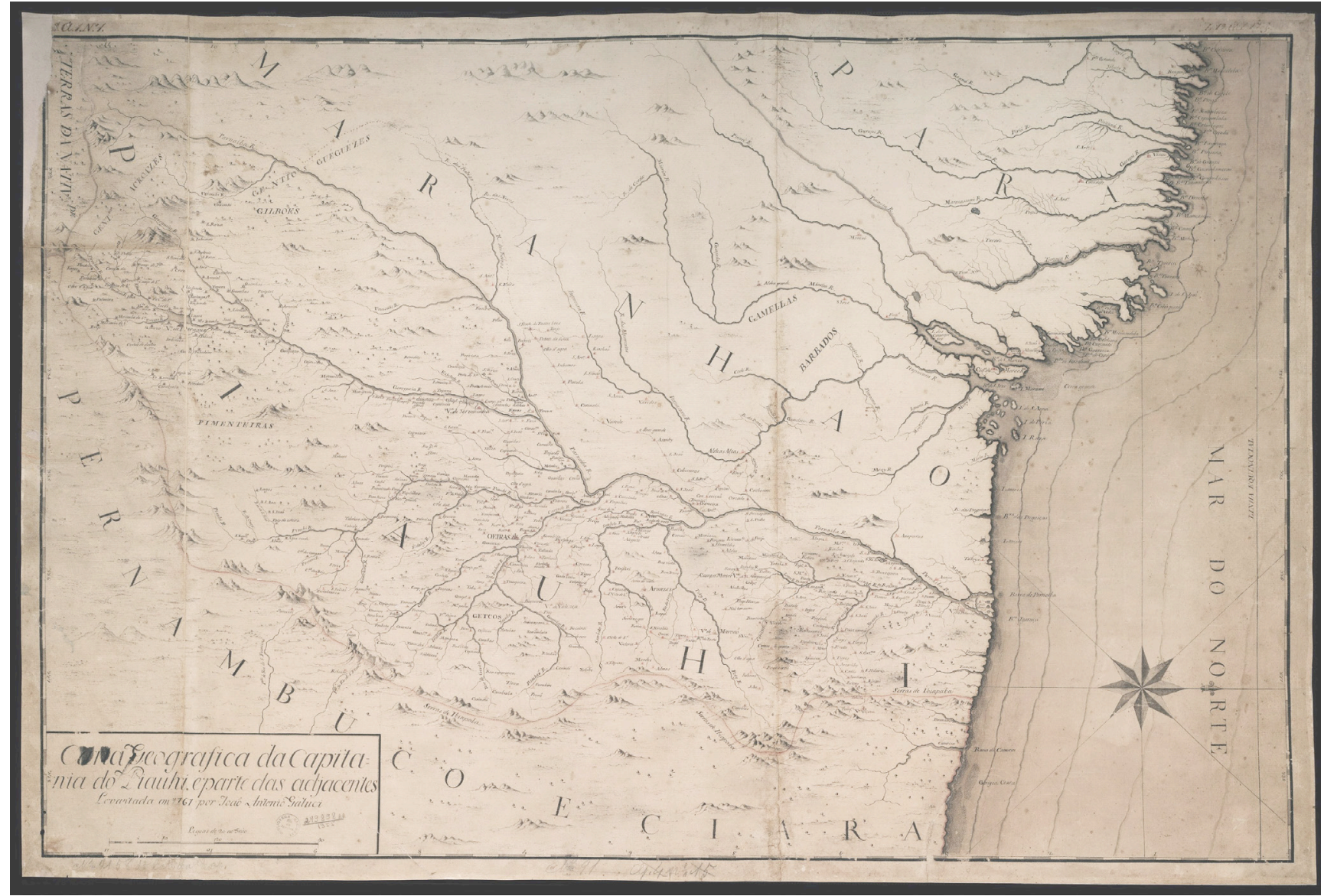

Figura 05 - Carta geografica da capitania do Piauhi, e parte das adjacentes levantada em 1761 por João Antônio Galuci. Original da Fundação da Biblioteca Nacional do Rio de Janeiro. Disponível em: <http:// www.bn.br> acesso em: 03 fev. 2010. público. estavam em andamento. $\bigcirc$ desembargador estabeleceu uma conexão entre o desenho e as vilas imaginadas: "...p. ${ }^{a}$ a vista delle interpor o meu parecer sobre os lugares que devem ser em $V$. ${ }^{\text {as }}$ erigidos, termos $q^{\prime}$ devem ter, e pessoas $q^{\prime}$ p. ${ }^{a} 0$ governo civil dellas achace mais idoneas..." 118.

Depois de demarcar e arrumar "...exactam. e; configurei geometricam. ${ }^{e}$ toda a costa maritima, q' medea entre a Cidade do Para, e da do Maranhão..." 119 , Galuzzi dirigiu-se ao Piauí, onde palmilhou "...toda aquela extrema largueza e vivendo innumeraveis dificuldades, determinando o rumo dos caminhos e fazendo repetidas observações de latitude e de longitude q' me foi possivel..." 20 . A Carta Geographica da Capitania do Piauhi, e partes adjacentes (Figura 05) é o resultado material e gráfico da viagem de levantamento do cartógrafo. Galuzzi se interessou em "riscar" as minúcias do território, pontuando as hierarquias dos assentamentos humanos como as sedes de fazendas, currais, povoações abandonadas, capelas filiais, paróquias, vilas e cidades (Figura 06). Não deixou de situar o sistema orográfico e hidrográfico da região, informações basilares à delimitação dos termos e jurisdições das futuras vilas e julgados. 


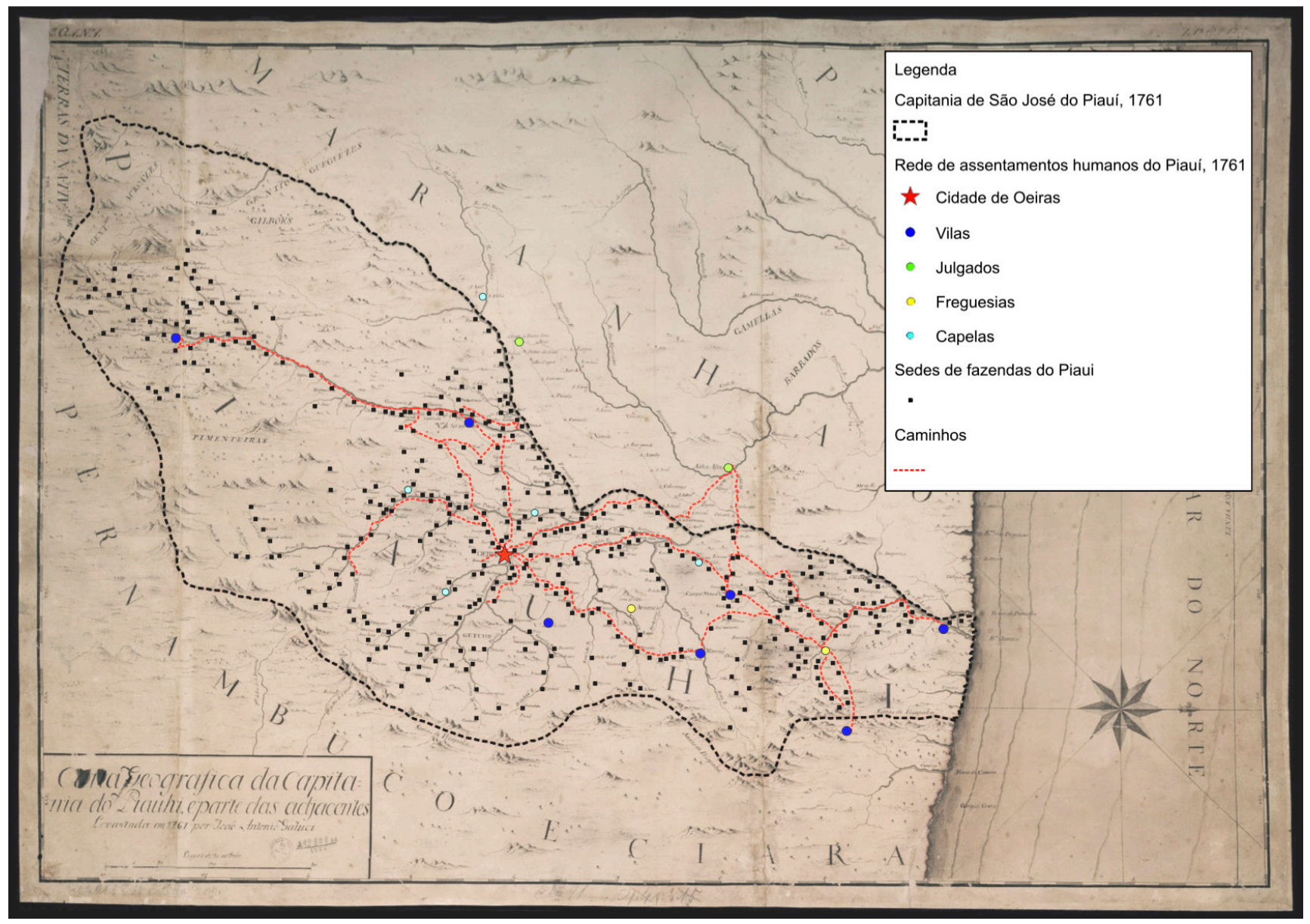

Figura 06 - Rede de povoações da capitania de São José do Piauí em 1761. Desenho do autor sobre a Carta geografica da Capitania do Piauhi, e parte das adjacentes levantada em 1761 por João Antônio Galuci. Mapa original da Fundação da Biblioteca Nacional do Rio de Janeiro. Disponível em: <http://www.bn.br>, acesso em 03 fev. 2010.

A paisagem transformada pelo homem é vista na simbologia empregada e na riqueza de topônimos elencados: há as fazendas Passagem, Tapera, 121. Ver Peter Burke (2005, p. 154) Mocambo, Engenho, Algodões, Vereda e Salinas para citar algumas. Apesar de não serem o ponto central do discurso do mapa, alguns aspectos culturais são frequentes na toponímia, na qual o catolicismo e os hibridismos, resultantes dos "encontros culturais"121 entre o colono europeu e o indígena, aparecem como conteúdo cartográfico e elementos constitutivos da construção da capitania: lê-se hagiotopónimos dedicados a São Nicolau, Santo Inácio, São João, Santa Rosa, Santa Ana, São Francisco, etc.; e endotopónimos como Macaita, Piripiri, Buriti, Itans, Itahim, Natuba, Genipapo, Guaribas, Curumim-Goara, Piracuruca, entre outros. De maneira que o discurso do mapa foi uma mediação dos processos de urbanização planeados por Francisco Marcelino de Gouveia e Pereira Caldas para - Piauí, pois materializava os ideias de regularização fundiária, de conversão 
122. Ver Renata Malcher de Araujo (2011, p. 10).

123. Cf. F. A. Oliveira Martins (1944, p. 34).

124. Cf. Arquivo Histórico Ultramarino_Administração Central_ Conselho Ultramarino_Piauí, Cx. 1, D. 41.

125. Cf. Arquivo Histórico Ultramarino_Administração Central Conse 1 ho Ultramarino_Piauí, Cx. 1, D. 48.

126. Cf. Arquivo Histórico Ultramarino_Administração Central Conse $1 \mathrm{ho}$ Ultramarino_Piauí, Cx. 6, D. 386.

127. Ver Renata Malcher de Araujo (2010, p. 190). social implícita na legislação indigenista e na construção do território relativa às vilas que o enquadraria ${ }^{122}$.

A Coroa, a partir do século XVII, homologou leis de combate à escravização dos índios buscando arregimentá-los ao seio da sociedade civil. Tencionava-se convertê-los de bárbaros e gentios a vassalos e filhos de Cristo, moldando-os às perspectivas culturais da Europa. Conseguia-se isso, em tese, por meio dos aldeamentos missioneiros e dos "lugares de índios" sugeridos pela política pombalina. $\bigcirc$ Piauí apresentou poucos aldeamentos voltados a cristianização e civilização dos neófitos. Além daqueles três fundados pelo vigário da vila da Mocha, Thomé de Carvalho e Silva, a documentação menciona mais dois: um localizado na freguesia de Nossa Senhora da Conceição dos Aroazes e outro implantado na ribeira do Itaim reunindo os índios Jaicós. Em 1728, João da Maia da Gama visitou o aglomerado dos Aroazes encontrando-o "... destrohido, e acabado com quarenta

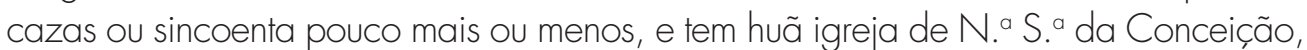
que he dos Indios, e da Mição que está com Micionario..." 123. Soma-se aos poucos aldeamentos missioneiros a "guerra justa" contra os "selvagens" que se tornou prática oficial quando os nativos resistiam à colonização.

O Sul da capitania foi um dos espaços onde os conflitos entre os colonos e os índios foram frequentes. Em 1722, o mestre de campo, Bernardo Carvalho Aguiar, declarava ao rei sobre sua participação na guerra "...contra o barbaro gentio no lugar q' chamão Parnaguá distante da Cid. " [São Luís] 150 leguas..." 124. Contra os ataques dos índios Timbira às fazendas de Parnaguá e da ribeira do rio Gurguéia, D. João V ordenou o envio de um exército indígena procedente do aldeamento da serra da lbiapaba, localizado na capitania do Ceará Grande, numa das fronteiras com o Piauí ${ }^{25}$. O mapa de Galuzzi materializou as tensões entre os colonizadores e os indígenas ocorridas naquela região por meio da indicação toponímica com letras em caixa alta de determinadas etnias - Gillboés, Guegués, Acroazes e Pimenteiras. $\bigcirc$ que qualifica essas áreas como espaços propriamente de tensão é a "ausência", isto é, o "vazio" como representação geográfica de regiões controladas pelas sociedades indígenas. A paisagem cartografada expõe a rala ou nula ocupação por currais, fazendas e capelas, dando às vistas apenas aspectos da geografia física como montanhas, ribeiras e bosques. Nessas fronteiras internas, chamadas por João Pereira Caldas de "fronteiras dos inimigos que experimentão maior vexação [aos colonos]"126, a Coroa formalizou projetos de controle e civilização da população nativa seguindo a normativa do Diretório dos Índios, de 1757. O diretório previa a integral liberdade indígena e a cessação total e completa do poder temporal das Ordens Religiosas sobre os nativos, em vez de converter - como faziam os religiosos imperava o ideal de civilizar. De acordo com a leitura de Renata Araújo, a transformação dos gentios em vassalos deve ser interpretada a partir de aspectos político-econômicos, isto é, era importante a integração das "fronteiras dos inimigos" ao quadro demográfico e territorial da colônia, mas também a sua inserção no aparato fiscal da Coroa, de que até então estavam excluídos ${ }^{127}$. 
A civilização dos índios e a submissão de regiões por eles controladas ocorreriam na conversão dos aldeamentos em vilas, experiência tirada das capitanias do Rio Negro, Grão-Pará e Maranhão, para onde o Diretório dos Índios havia sido inicialmente destinado ${ }^{128}$. É o que se verificou na viagem de demarcação. João Pereira Caldas relatou, em 25 de janeiro de 1760, sua intenção de erigir em vila "...huma [povoação] de Indios da Nasçao dos Jaicós..." 129 . Esse mesmo projeto apareceria meses depois num ofício encaminhado a Francisco Xavier de Mendonça Furtado, no qual o governador interessava-se em "Brevemente hir erigir em Villa hum lugar de Indios, que dista desta Villa [Mocha], cousa de trinta e tantas legoas, sendo o unico que deve passar a vila, pois o outro que há [Aroazes], he tão pequeno que estou na resolução de unir ao sobred. …" ${ }^{130}$. Em suma, tem-se o plano reformista da capitania concluído pelo desembargador, governador, ouvidor e engenheiro militar, no qual a criação de três vilas (Paranguá, Surubim e mais uma de índios) e quatro julgados (Piracuruca, Rancho do Prato, Buriti dos Lopes e Gurguéia) formariam um território hierarquizado e urbano. Não obstante, a Coroa tinha outras intenções para o Piauí, que foram além dos projetos de seus representantes...

Novos horizontes urbanos: a capitania do Piauí construída pela carta régia de 19 de junho de 1761

D. José I decidiu outro plano para a capitania, indo além dos pareceres apresentados nos relatórios das autoridades depois da conclusão da viagem das demarcações. A solução encontrada veio por meio da carta régia de 19 de junho de 1761, cujo conteúdo indica procedimentos jurídicos e formais para a fundação de vilas seguindo um modelo razoavelmente padronizado em outros casos da colônia. Nela, a Coroa explicita a conversão das seis paróquias em vilas, em vez de três como sugerido pelo governador João Pereira Caldas. Inverteu-se o projeto do desembargador Francisco Marcelino de Gouveia: em vez de julgados, vilas. Os julgados eram "remédios" paliativos para os problemas judiciais e administrativos vivenciados pela população que, nos casos mais graves, deveria apelar às justiças das câmaras às quais estava subordinada ${ }^{131}$. $\bigcirc$ ponto alto do documento, porém, refere-se à determinação de elevar a vila da Mocha à qualidade de cidade, centro administrativo do governo criado em 1758, fazendo-se uma das capitais da rede urbana do Estado do Grão-Pará e Maranhão, posicionada no mesmo patamar hierárquico de Belém e São Luís.

A Coroa justificou no início da carta a reestruturação urbana da capitania acompanhada de um novo paradigma ético, estético, espacial e cronológico a ser vivenciado pelos povoadores. A seu ver, a anterior malha de paróquias e de assentamentos humanos era responsável pelo moroso desenvolvimento econômico e da pouca "civilidade" dos seus habitantes, porque viviam "...em grandes distancias huns dos outros sem comunicação, como inimigos
128. Ver Idem (2013, p. 98).

129. Cf. Arquivo Histórico Ultramarino_Administração Central_ Conse 1 h o Ultramarino_Piauí, Cx. 6, D. 381.

130. Cf. Arquivo Histórico Ultramarino_Administração Central_Consel ho Ultramarino_Piauí, Cx. 7, D. 407.

131. Ver Cláudia Damasceno Fonseca (2011, p. 191). 
132. Cf. Arquivo Histórico Ultramarino_Administração Central_Cons e 1 ho Ultramarino_Piauí, Cx.8, D. 457.

133. Ver Renata Malcher de Araujo (2011, p. 08).

134. Cf. Arquivo Histórico Ultramarino_Administração Central_ Conse $1 \mathrm{~h}$ o Ultramarino_Piauí, Cx. 6, D. 395.

135. Cf. Arquivo Histórico Ultramarino_Administração Central_ Conse $1 \mathrm{~h}$ o Ultramarino_Piauí, Cx. 8, D. 457.

\section{Cf. Ibid.}

137. Cf. Arquivo Histórico Ultramarino_Administração Central_ Conse 1 h o Ultramarino_Piauí, Cx. 8, D. 507.

138. Cf. Arquivo Histórico Ultramarino_Administração Central_ Conselho Ultramarino_Piauí, Cx. 8, D. 514.

\section{Cf. Ibid.}

\section{Cf. Ibid.}

141. Cf. Arquivo Histórico Ultramarino_Administração Central_ Conse 1 h o Ultramarino_Piauí, Cx. 8, D. 457.

142. Ver Íris Kantor (2009, p. 50). da sociedade civil, e do comércio humano, padecendo assim os discomodos, e as despesas de hirem buscar os Magistrados a lugares remotos..."132. As vilas configurariam reformas estruturais no Piauí e incitariam um novo modo de vida, fundamentando uma existência consagrada no urbano como o locus da civilidade $^{133}$, mesmo que a materialidade desse urbano não autenticasse a "dignidade" concedida pelo rei. Vale evocar mais uma vez o diagnóstico de Marcelino de Gouveia, no qual as povoações das freguesias de Nossa Senhora do Carmo de Piracuruca, Nossa Senhora do Desterro do Rancho do Prato, Nossa Senhora da Conceição dos Aroazes e Santo António do Gurguéia representavam a "incapacidade" e, por isso, "...não podem lembrar para dellas se fazer memoria para o fim sobred. ... de ser Villas erigidas..." 134 .

Impulsionava-se, ainda, a fixação de habitantes dispersos pelos sítios e fazendas, garantindo-thes isenções fiscais e outros privilégios nos três primeiros anos, exceto "...os Dizimos devidos a Deus dos fructos da terá, os quaes deverão pagar sempre, como os mais moradores do Estado..." 135 . Em seguida, os funcionários régios e os povoadores das vilas foram admoestados a "... determinar o lugar mais próprio para servir de Praça a cada huma das ditas Villas..." 136 . Nesse aspecto, Francisco Marcelino de Gouveia, João Pereira Caldas e o ouvidor Luís José Duarte Freire realizaram uma segunda jornada pela capitania, iniciada em maio de 1762, no intuito de cumprirem o expediente régio. As vilas fundadas em Parnaguá, Surubim, Gurguéia e Rancho do Prato foram implantadas "...no mesmo lugar em que se acha a Parochia..." 137 . As estabelecidas nas freguesias de Piracuruca e Aroazes, obtiveram um novo sítio de instalação. A primeira assentou-se nas proximidades do mar, no lugar chamado Testa Branca ${ }^{138}$, onde sumacas provenientes do Maranhão, Ceará Grande, Pernambuco, Bahia e Rio de Janeiro comercializavam gado, carne e couro. Em Aroazes, os representantes do rei e do povo desconsideraram a localização da povoação "...em que havia vinte e hum fogos, de índios a mayor parte, e mais quatro lemitadissimas casas, não habitadas, e indignas de o serem..." 139 , optando-se pelo "...lugar da Cotinguinha, e na distancia de nove legoas da dita Parochia..."140. Nessa ocasião, determinavam-se as dimensões do termo, do rossio e do patrimônio dos concelhos recém-emancipados.

A transformação das freguesias em vilas e a vila da Mocha em cidade se deu juntamente na esfera imaterial quando $D$. José I decretou que se renomeassem as municipalidades "...impondo-thes os nomes das Villas mais notaveis deste Reyno, ou concervando o das referidas Freguezias no caso, que não sejão barbaros..."141. O Diretório dos Índios havia instruído essa operação anos antes para os aldeamentos missioneiros das capitanias do Rio Negro, Pará e Maranhão. Conforme escreveu a historiadora Íris Kantor ${ }^{142}$, a nova toponímia representaria um simulacro da metropolitana, fazendo parte de uma ampla política de secularização da administração colonial orquestrada pelo marquês de Pombal. $\bigcirc$ rebatismo significava um "renascimento" não apenas nos espectros simbólico e ideológico, mas seguiram critérios políticos pragmáticos de homenagem precisa, tendo a clara intenção de reafirmar uma geografia essencialmente portuguesa por invocar os 
concelhos do reino ${ }^{143}$. Assim, Mocha tornou-se a cidade de Oeiras do Piauí em óbvia honra ao Conde de Oeiras, o articulador das políticas de D. José I. As povoações de Santo António do Surubim, Nossa Senhora do Desterro do Rancho do Prato e Santo António do Gurguéia converteram-se, respectivamente, em Campo Maior, Marvão e Jerumenha. Em Piracuruca e Aroazes, as autoridades implantaram as vilas de São João de Parnaíba e Valença do Piauí. Parnaguá foi a única vila a manter a nomenclatura original.

Acompanhada da carta régia veio uma missiva de Francisco Xavier de Mendonça Furtado ao governador João Pereira Caldas esclarecendo as razões pelas quais a Coroa decidiu elevar todas as paróquias da capitania à vila, em vez de concretizar as resoluções tomadas após a experiência das viagens ${ }^{144}$. Mendonça Furtado enquadrou o plano régio em seis níveis: o primeiro abordou a pobreza social e física das povoações como injustificáveis à sua exclusão ao título de vila, embora "...S. Mag. de ficou persuadido a q' presentem. ${ }^{\text {te }}$ as terras em q' aquellas Freguesias excluídas estão situadas se achão em toda a pobreza, e desolação, q' o d. o Ministro se refere em sua bem explicada conta"145. A implantação das vilas era compreendida como um benefício, uma graça régia a fim de iluminar "...a rudez desses povos, e excitem nelles a louvavel ambição do seu aumento" 146 . Concedida a mercê dava-se início a uma rede de pactos negociados entre o ofertante e o receptor. Os concelhos desempenhariam um papel intermediário entre eles $^{147}$. Com efeito, o novo predicamento gerava uma expectativa futura ao rei de ver florescidas, social e urbanisticamente, as vilas criadas.

A segunda razão das reformas da Coroa refere-se à comunicação, aparecendo, explicitamente, no texto da carta régia. Buscava-se reduzir as distâncias entre os moradores e as vilas, incentivando a vida urbana "...por cuja razão as pessoas distintas, ou que se procurão distinguir, costumão viver nas cidades, e villas, e terem nas fazendas Criados, e administradores, para tratarem dellas..."148. Aqui, os núcleos urbanos do reino assumem a representação da civilidade e distinção social, sendo modelos a imitar pelos povos decididos a sair da "escuridão" à luz da civilização. Ademais, as elites das cidades articulavam-se entre o urbano, o periurbano e o rural, movimentando trocas sociais e econômicas numa rede urdida em dimensão macro. Por conseguinte, pretendia-se que no Piauí essas instâncias se relacionassem dinamicamente, movimentando o comércio tanto internamente como externamente, remetendo os seus produtos às outras capitanias da colônia.

A regularidade pastoral, oriunda dos curtos deslocamentos do pároco durante as desobrigas anuais, aparecem no terceiro ponto arrolado pelo secretário de Estado da Marinha e Ultramar. Também se objetivava a regularidade fiscal da coleta dos dízimos dos frutos da terra. Esse quesito aliava-se ao quinto veiculado à construção das igrejas matrizes, casas de câmara e cadeias nas vilas projetadas com recursos tanto da Fazenda Real como dos dízimos, ". . .lembrando sempre aos fregueses as obrigações, q' por direito canonico, e civil tem de fazerem as sobred. as obras..." 149.
143. Ver Renata Malcher de Araujo (2013, p. 190).

144. Cf. Arquivo Histórico Ultramarino_Administração Central_Conse 1 ho Ultramarino_Piauí, Cx. 8, D. 457. Este documento aparece transcrito em F. A. Pereira da Costa (1974, p. 147-149).

145. Cf. Arquivo Histórico Ultramarino_Administração Central_Consel ho Ultramarino_Piauí, Cx. 8, D. 457.

146. Cf. Ibid.

147. Ver António Manuel Hespanha (2005, p. 08).

148. Cf. Arquivo Histórico Ultramarino_Administração Central_Consel ho Ultramarino_Piauí, Cx. 8, D. 457.

149. Cf. Ibid. 
150. Cf. Ibid.

151. Cf. Arquivo Histórico Ultramarino_Administração Central_ Conse 1 h o Ultramarino_Piauí, Cx. 10, D. 587.

152. Cf. Arquivo Histórico Ultramarino_Administração Central_ Consel ho Ultramarino_Piauí, Cx. 11, D. 642.

153. Cf. Arquivo Histórico Ultramarino_Administração Central_Conse $1 \mathrm{ho}$ Ultramarino_Piauí, Cx. 8, D. 457.
Voltando ao quarto motivo, recomendava-se a eleição, por parte "... das pessoas mais principais e consideraveis...", do lugar "...mais proprio para a fundação da vila..." 150 . A construção da capitania e de sua rede urbana, dessa forma, seguiram, mais uma vez, critérios utilitaristas e éticos. Utilitário no sentido de situar as vilas em localidades convenientes, como afirmou João Pereira Caldas ao dar andamento aos imperativos régios: "Foy S. Mag. de servido determinar, $q$ ' junto das Villas, q' por ella [carta régia] mandou fundar, se devia reservar aquelle Districto, $q^{\prime}$ me pareceo conveniente $p .{ }^{a}$ a edificação das novas casas, e logradouros públicos"151. A conveniência, considerada brevemente quando tratamos da oficialização da freguesia de Nossa Senhora da Vitória, relacionavase à utilidade do território, que deveria ser guarnecido de água, plano, higiênico e sem impeditivos ao progresso físico da vila. Relembremos dos casos de São João de Parnaíba e Valença do Piauí transferidas para outras localidades dos seus concelhos. A vila de Parnaíba ainda é mais emblemática porque as autoridades e o povo escolheram um sítio - Testa Branca - em vez do Porto das Barcas, ancoradouro das sumacas e onde existiram feitorias de carne e curtimento de couros, porém apresentava-se "... desconveniente de serem as agoas do rio salobras em ocasião de maré chea, e ainda vazia, e ficão as madeiras muito distantes e a praga dos mosquitos he tanta q' o faz inhabitavel, e incapaz de morar gente..." ${ }^{152}$.

Finalmente, na sexta orientação, Francisco Xavier de Mendonça Furtado declarava o estabelecimento de seis ou sete famílias, o erguimento do pelourinho e a construção da igreja matriz, casa de câmara e cadeia, materialidades que, aos seus olhos, catalisavam os processos de adensamento populacional das vilas. Com efeito, essa medida não era fortuita, mas orientada segundo os resultados colhidos em vilas "... plantadas no Territorio da capp. nia da Bahia, os quaes havendo principiado ha pôcosannos, por seis, ou sete casas, se achão populozas até o n. ${ }^{\text {ro }}$ de quinhentos, e seiscentos vizinhos..."153.

\section{Consideração final}

Sob essa complexidade social e material construiu-se a capitania de São José do Piauí. As suas dimensões variaram descontinuamente no tempo e no espaço. Quando o "Piauí" ainda era conteúdo dos Sertões de Rodelas, a Coroa e seus representantes orquestraram políticas voltadas a reorganizar as terras e as sociedades dentro deles. Naquela altura, o bispo D. Frei Francisco de Lima, o governador da capitania de Pernambuco, Caetano de Melo e Castro, e o Conselho Ultramarino possuíam a noção de uma região com contornos imprecisos, passível de reformas territoriais e ocupação efetiva. Em 1718, criou-se a comarca e capitania com limites incertos, às vezes ultrapassando as circunscrições limítrofes, e não tardou a surgir conflitos entre os oficiais, civis e eclesiásticos das áreas adjacentes. No entanto, a construção do Piauí veio a partir de 1758, durante as "grandes demarcações", quando D. José I autonomizou a capitania. Fez-se, inclusive, por texto e imagem, por meio da carta régia de 19 de junho de 1761 
e pelo mapa de Henrique António Galuzzi, no qual literalmente há os limites definidos e calculados segundo o rigor geométrico e astronômico da época. Os textos dos representantes do rei, a carta geográfica e a rede urbana equacionada por uma cidade e seis vilas enquadraram-se como discurso de uma cronologia baseada nas reformas de uma política abrangente, cujas irregularidades seriam dirimidas "plantando vilas" onde requeria-se.

\section{REFERÊNCIAS}

\section{FONTES TEXTUAIS PRIMÁRIAS MANUSCRITAS}

\section{Arquivo Histórico Ultramarino}

Documentos manuscritos avulsos referentes à capitania da Bahia

Bahia, 6 de maio de 1757

OFÍCIO do vice-rei, conde dos Arcos, para Tomé Joaquim da Costa Corte Real, participandolhe ter ordenado a todos os ouvidores das comarcas que mandassem a todas as camaras das mesmas comarcas fizessem cada huma dellas huma relação dos lugares e povoações do seu districto com os nomes e as distancias que ha de humas ás outras, practicando-se a mesma descripção dos rios, que pelas ditas povoações passão, individuando os seus nascimentos e os que são navegáveis e que em cada huma das villas se declararião a distancia de legoas ou dias de jornada, que hião ás outras villas circunvizinhas. Arquivo Histórico Ultramarino_ Administração Central_Conselho Ultramarino_Bahia, Cx. 13, D. 2447.

Documentos manuscritos avulsos referentes à capitania do Maranhão

1 de fevereiro de 1712, Lisboa

CONSULTA do Conselho Ultramarino ao rei D. João V, sobre a resposta do ouvidor-geral do Estado do Maranhão, Eusébio Capelli, acerca da nomeação de um juiz de fora ou ouvidor para a capitania do Piauí. Arquivo Histórico Ultramarino_Administração Central_Conselho Ultramarino_Maranhão, Cx. 11, D. 1138.

5 de julho de 1746, Lisboa

CONSULTA do Conselho Ultramarino ao rei D. João V, sobre a solicitação que o ouvidorgeral da capitania do Maranhão, Francisco Raimundo de Morais Pereira, fez para se criar, nos distritos de Parnaíba, Aldeias Altas e Mearim, os cargos de juiz ordinário com seu escrivão”. Arquivo Histórico Ultramarino_Administração Central_Conselho Ultramarino_Maranhão, Cx. 29, D. 2978. 
18 de outubro de 1756, São Luís do Maranhão

OFÍCIO do governador do bispado do Maranhão, João Rodrigues Covete, para o secretário de estado da Marinha e Ultramar, Tomé Joaquim da Costa Corte Real, sobre a apresentação de uma relação dos lugares e povoações das freguesias da diocese, das distancias entre elas e os seus respectivos nomes. Arquivo Histórico Ultramarino_Administração Central_Conselho Ultramarino_Maranhão, Cx. 37, D. 3671.

Documentos manuscritos avulsos referentes à capitania da Paraíba

5 de junho de 1710, Paraíba

CARTA do capitão-mor da Paraíba, João da Maia da Gama, ao rei [D. João V], sobre os povoados, gados e mais fazendas, e a falta de administração nos sertões. Arquivo Histórico Ultramarino_Administração Central_Conselho Ultramarino_Paraíba, Cx. 4, D. 310.

Documentos manuscritos avulsos referentes à capitania de Pernambuco

29 de outubro de 1697, Lisboa

CONSUlTA da Junta das Missões ao rei [D. Pedro II] sobre a carta do bispo de Pernambuco, [D. frei Francisco de Lima] e do governador da capitania [Caetano de Melo de Castro], acerca da falta de igrejas e párocos nos presidios dos Palmares e Sertão de Rodelas, dos delitos cometidos na região, e da dissolução em que vive o mestre-de-campo do presídio de Alagoas. Arquivo Histórico Ultramarino_Administração Central_Conselho Ultramarino_Pernambuco, Cx. 17, D. 1732.

20 de janeiro de 1699, Lisboa

CARTA RÉGIA do rei [D. Pedro II] ao governador da capitania de Pernambuco [Caetano de Melo e Castro], ordenando as normas para o povoamento e assentamento de datas de terra no sertão. Arquivo Histórico Ultramarino_Administração Central_Conselho Ultramarino_ Pernambuco, Cx. 18, D. 1771.

25 de setembro de 1703, Lisboa

CONSULTA do Conselho Ultramarino ao rei D. Pedro II, sobre a carta do governador geral do Estado do Brasil, D. Rodrigo da Costa, acerca do aviso do governador da capitania de Pernambuco, Francisco de Castro de Moraes, a respeito da guerra contra o gentio da nação Macarus, habitantes das terras da região do salitre, do rio São Francisco, da parte da capitania de Pernambuco. Arquivo Histórico Ultramarino_Administração Central_Conselho Ultramarino_Pernambuco, Cx. 20, D. 1941. 
ant. 1784, 6 de agosto, Freguesia de Cabrobó

"Requerimento do tenente coronel e comandante das Freguesias de Rodelas e Cabobó, Francisco de Matos Henriques, à rainha [D.Maria I], pedindo a criação de um cargo de ministro de vara branca ou um governo civil e político para as ditas freguesias, ou ainda que o ministro de Sergipe Del Rei ou de Oeiras pratiquem lá suas correições e justiça. Arquivo Histórico Ultramarino_Administração Central_Conselho Ultramarino_Pernambuco, Cx. 152, D. 11015.

Documentos manuscritos avulsos referentes à capitania do Piauí

ant. 1723, 23 de janeiro, Lisboa

REQUERIMENTO do ouvidor-geral nomeado para a vila da Mocha, Antonio Marques Cardoso, ao rei [D. João V], solicitando que se conceda perdão aos criminosos da sua jurisdição e autorização para a criação de novas vilas, ofícios e construção da casa de câmara e cadeia. Arquivo Histórico Ultramarino_AdministraçãoCentral_ConselhoUltramarino_Piauí, Cx. 1, D. 19.

31 de agosto de 1724, Belém do Pará

CARTA do governador e capitão general do Maranhão, João da Maia da Gama, ao rei [D. João V], sobre a chegada e habilitação do novo ouvidor-geral do Piauí, Antonio Marques Cardoso. Arquivo Histórico Ultramarino_AdministraçãoCentral_ConselhoUltramarino_Piauí, Cx. 1, D. 26.

10 de janeiro de 1727 , vila da Mocha

CARTA do ouvidor geral do Piauí, Antonio Marques Cardoso, ao rei [D. João V], sobre as medidas judiciais que tem administrado na sua jurisdição. Arquivo Histórico Ultramarino_ AdministraçãoCentral_ConselhoUltramarino_Piauí, Cx. 1, D. 32.

3 de outubro de 1727 , vila da Mocha

CARTA do ouvidor geral do Piauí, Antonio Marques Cardoso, ao rei [D. João V], sobre a passagem da vila da Mocha para a jurisdição da Bahia ou Maranhão; os danos causados pelo gentio e a necessidade de uma cadeia e solicita que a Câmara desta vila possa fazer concessão de terras". AHU_ACL_CU_Piauí, Cx. 16, D. 35.

Ant. 1728, 27 de setembro

REQUERIMENTO do mestre de campo, Bernardo de Carvalho Aguiar, ao rei [D. João V], solicitando anulação da nota inscrita no seu assento, que lhe dá baixa de soldo, correspondente à guerra do gentio em Parnaguá. Arquivo Histórico Ultramarino_Administração Central_ Conselho Ultramarino_Piauí, Cx. 1, D. 41. 
CARTA do governador do Bispado do Maranhão, Antonio Troyano, ao rei [D. João V], sobre a sua tomada de posse na jurisdição espiritual do Piauí e informando acerca da administração religiosa. Arquivo Histórico Ultramarino_AdministraçãoCentral_ConselhoUltramarino_Piauí, Cx. 1, D. 45.

16 de julho de 1729, São Luís do Maranhão

CARTA do governador e capitão-general do Estado do Maranhão, Alexandre de Sousa Freire, ao rei [D. João V], em resposta à provisão sobre a continuação das hostilidades perpetuadas pelos índios, e da licença que concedeu aos moradores de Parnaguá para que constituam uma tropa de combate a esses ataques. Documento avulso. Arquivo Histórico Ultramarino_ Administração Central_Conselho Ultramarino_Piauí, Cx. 1, D. 48.

1 de maio de 1731, vila da Mocha

CARTA do ouvidor-geral do Piauí, José de Barros Coelho, ao rei [D. João V], sobre a necessidade de nomear juiz ordinário para Parnaguá, em virtude da distância deste local à vila da Moucha. Arquivo Histórico Ultramarino_Administração Central_Conselho Ultramarino_ Piauí, Cx. 1, D. 65.

26 de fevereiro de 1732, vila da Mocha

CARTA do ouvidor do Piauí, José de Barros Coelho, ao rei [D. João V], sobre as razões porque não mandou construir hospício no Piauí. Documento anexo. Arquivo Histórico Ultramarino_ AdministraçãoCentral_ConselhoUltramarino_Piauí, Cx. 2, D. 75.

16 de maio de 1733, vila da Mocha

CARTA o ouvidor geral do Piauí, José de Barros Coelho, ao rei [D. João V], sobre os requerimentos do vigário da igreja matriz de Nossa Senhora da Vitória do Piauí, padre Tomé Carvalho e Silva, solicitando ornamentos para a igreja, ajudas de custo e pagamento das côngruas em atraso. Arquivo Histórico Ultramarino_Administração Central_Conselho Ultramarino_Piauí, Cx. 2, D. 96.

Post. 1742, 22 de maio, vila da Mocha

REQUERIMENTO do vice-vigário da freguesia de Nossa Senhora da Vitória, João Rodrigues Covete, ao rei [D. João V], solicitando provisão para acrescentar 20 mil réis de côngrua aos vigário de sua freguesia. Arquivo Histórico Ultramarino_Administração Central_Conselho Ultramarino_Piauí, Cx. 3, D. 185. 
PROVISÃO (cópia) do rei D. José ao governador e capitão-general do Maranhão [Gonçalo Pereira Lobato de Sousa], sobre as demarcações das sesmarias, no sertão da Parnaíba, só podendo ser feita pelo ouvidor. Arquivo Histórico Ultramarino_Administração Central_ Conselho Ultramarino_Piauí, Cx. 5, D. 342.

2 de agosto de 1758, Lisboa

OFÍCIO (cópia) do secretário de estado da Marinha e Ultramar, Tomé Joaquim da Costa Corte Real, ao governador e capitão-general do Pará, Francisco Xavier de Mendonça Furtado, sobre a criação da capitania do Piauí e da nomeação de João Pereira Caldas para o cargo de governador e de outras pessoas para cargos administrativos. Arquivo Histórico Ultramarino_ Administração Central_Conselho Ultramarino_Piauí, Cx. 5, D. 359.

7 de março de 1759, vila da Mocha

OFÍCIO do desembargador Francisco Marcelino de Gouveia, ao secretário de estado da Marinha e Ultramar [Tomé Joaquim da Costa Corte Real], sobre a administração da justiça no Piauí, referindo-se às devassas que realizou e às demarcações das sesmarias feitas por Custódio Correia de Matos. Arquivo Histórico Ultramarino_Administração Central_Conselho Ultramarino_Piauí, Cx. 5, D. 365.

20 de janeiro de 1760, vila da Mocha

CARTA do governador do Piauí, João Pereira Caldas, ao rei [D. José I], sobre as causas da decadência do comércio do Piauí. Arquivo Histórico Ultramarino_Administração Central_ Conselho Ultramarino_Piauí, Cx. 6, D. 378.

25 de janeiro de 1760, vila da Mocha

OFÍCIO do governador do Piauí, João Pereira Caldas, ao secretário de estado da Marinha e Ultramar, Tomé Joaquim da Costa Corte Real, sobre a sua tomada de posse do governo e o estado em que encontrou a capitania”. Arquivo Histórico Ultramarino_Administração Central_ Conselho Ultramarino_Piauí, Cx. 6, D. 381.

26 de janeiro de 1760, vila da Mocha

OFíCIO do governador do Piauí, João Pereira Caldas, ao secretário de estado da Marinha e Ultramar, Tomé Joaquim da Costa Corte Real, sobre a guerra que se deve fazer ao gentio, em virtude das queixas dos habitantes de Parnaguá". Arquivo Histórico Ultramarino_ Administração Central_Conselho Ultramarino_Piauí, Cx. 6, D. 386. 
6 de fevereiro de 1760, vila da Mocha

OFÍCIO do desembargador Francisco Marcelino de Gouveia ao secretário de estado da Marinha e Ultramar, Tomé Joaquim de Costa Corte Real, sobre a falta de segurança na povoação de Pastos Bons, em razão do juiz responsável estar em Aldeias Altas. Arquivo Histórico Ultramarino_Administração Central_Conselho Ultramarino_Piauí, Cx. 6, D. 389.

20 de fevereiro de 1760, vila da Mocha

OFÍCIO do desembargador, Francisco Marcelino de Gouveia, ao secretário de estado da Marinha e Ultramar, Tomé Joaquim da Costa Corte Real, sobre o plano que efectuou do território do Piauí e da divisão do mesmo em duas ouvidorias; remetendo uma lista de pessoas que poderão trabalhar no governo civil da capitania. Arquivo Histórico Ultramarino_ Administração Central_Conselho Ultramarino_Piauí, Cx. 6, D. 395.

13 de março de 1760, vila da Mocha

OFíCIO do governador do Piauí, João Pereira Caldas, ao secretário de estado da Marinha e Ultramar, Francisco Xavier de Mendonça Furtado, sobre a sua tomada de posse e o estado em que encontrou a capitania, a expulsão dos padres da Companhia de Jesus e o sequestro dos seus bens; descreve a criação do Regimento de Cavalaria e a sua intenção em fundar uma aldeia indígena. Arquivo Histórico Ultramarino_Administração Central_Conselho Ultramarino_Piauí, Cx. 7, D. 407.

23 de outubro de 1760, vila da Mocha

OFÍCIO do desembargador, Francisco Marcelino de Gouveia, a Franciso Xavier de Mendonça Furtado, sobre o cumprimento da execução de um plano geral da capitania, no que se refere a uma boa administração da justiça e arrematação dos dízimos reais. Arquivo Histórico Ultramarino_Administração Central_Conselho Ultramarino_Piauí, Cx. 7, D. 435.

21 de novembro de 1760, vila da Mocha

OFíCIO do governador do Piauí, João Pereira Caldas, a Francisco Xavier de Mendonça Furtado, sobre as medidas tomadas com as fazendas administradas pelos jesuítas e doadas aos oficiais de Cavalaria; acerca dos trabalhos que estava encarregado o engenheiro Henrique Antonio Gallucio, remetendo o requerimento em que este solicita a nomeação para sargentomor engenheiro, com soldo dobrado. Arquivo Histórico Ultramarino_Administração Central_ Conselho Ultramarino_Piauí, Cx. 7, D. 436. 
23 de novembro de 1760, vila da Mocha

OFÍCIO do engenheiro, Henrique António Gallucio, a Francisco Xavier de Mendonça Furtado, sobre as configurações geométricas que efetuou em toda a costa marítima, desde Pará ao Maranhão e capitania do Piauí, para a elaboração de cartas geográficas da capitania, enviando um requerimento a solicitar a sua nomeação para o cargo de sargento-mor engenheiro, com soldo dobrado. Arquivo Histórico Ultramarino_Administração Central_Conselho Ultramarino_ Piauí, Cx. 7, D. 437.

19 de junho de 1761, Lisboa

CARTA RÉGIA (cópia) do rei, D. José I, ao governador do Piauí, João Pereira Caldas, ordenando a fundação de vilas na capitania do Piauí, passando a vila da Mocha a ser capital do governo e dando outras medidas administrativas para o governo da capitania. Arquivo Histórico Ultramarino_Administração Central_Conselho Ultramarino_Piauí, Cx. 8, D. 457.

13 de julho de 1762, Oeiras do Piauí

OFÍCIO do desembargador, Francisco Marcelino de Gouveia, ao secretário de estado da Marinha e Ultramar, Francisco Xavier de Mendonça Furtado, sobre a criação da nova povoação de Nossa Senhora do Livramento, na freguesia de Parnaguá. Documento avulso. Arquivo Histórico Ultramarino_Administração Central_Conselho Ultramarino_Piauí, Cx. 8, D. 507.

17 de novembro de 1762, Oeiras do Piauí

OFÍCIO do desembargador Francisco Marcelino de Gouveia ao secretário de estado da Marinha e Ultramar, Francisco Xavier de Mendonça Furtado, sobre as diligências efectuadas para a edificação das novas vilas do Piauí. Arquivo Histórico Ultramarino_Administração Central_Conselho Ultramarino_Piauí, Cx. 8, D. 514 .

28 de outubro de 1767, Oeiras do Piauí

OFÍCIO do governador do Piauí, João Pereira Caldas, ao secretário de estado da Marinha e Ultramar, Francisco Xavier de Mendonça Furtado, sobre a edificação das novas casas e edifícios públicos a construir nas novas povoações e acerca de suas dúvidas nas condições e distribuições de datas e sesmarias pelos habitantes destes locais. Arquivo Histórico Ultramarino_Administração Central_Conselho Ultramarino_Piauí, Cx. 10, D. 587. 
20 de julho de 1770, Oeiras do Piauí

CARTA do governador do Piauí, Gonçalo Lourenço Botelho de Castro, ao rei [D. José I], sobre a organização das novas vilas criadas na capitania do Piauí, as dificuldades que tem havido no estabelecimento dos edifícios públicos nas mesmas, e solicitando soluções a este respeito. Arquivo Histórico Ultramarino_Administração Central_Conselho Ultramarino_Piauí, Cx. 11, D. 642.

Arquivo Nacional da Torre do Tombo (ANTT)

Ordem de Cristo, Padroado do Brasil, Arcebispado da Bahia.

Biblioteca Nacional de Portugal - Colecção Pombalina

REGISTRO das cartas em geral das duas capitanias do Pará e Rio Negro, que escreve o Ill. moe Ex.mo Sr. Francisco Xavier de Mendonça Furtado, Governador e Capitão General do Estado do Grão Pará e Maranhão. Correspondencia official (1754-1758). Colecção Pombalina. Biblioteca Nacional de Portugal.

\section{FONTES TEXTUAIS PRIMÁRIAS IMPRESSAS}

BLUTEAU, Raphael. Vocabulario portuguezE latino: aulico, anatomico, architectonico (...). Coimbra: Collegio das Artes da Companhia de Jesus, 1712 - 1728. 8 v. Disponível em http:// www.brasiliana.usp.br, acesso em 24 nov 2015.

CARTA do rei D. João V ao ouvidor geral do Maranhão, sobre se lhe ordenar se passe a Piauhy a criar huma Villa com Senado da Camara. Anais da Biblioteca Nacional do Rio de Janeiro. Vol. 66 (O livro grosso do Maranhão, 2. parte). Rio de Janeiro, 1948. p. 104-105.

CARTA autografa de D. Francisco Lima, Bispo de Pernambuco, de 11 de Junho de 1697, remetendo a Roque Monteiro Paim a descrição do Sertão de Piagui. In: ENNES, Ernesto. $A$ guerra dos Palmares. Rio de Janeiro: Cia. Editora Nacional, 1938. p. 362.

CONSUlTA do Cons. ${ }^{\circ}$ Ultr. $^{\circ}$ de 12 de Dez. ${ }^{\circ}$ de 697 , com a consulta incluza da Junta das Missões sobre o q' escreverão o Bispo , e gov. ${ }^{\text {or }}$ de Pern. ${ }^{\text {co }}$ acerca da falta de Igrejas, e Parrochos nos Presidios dos Palmares e certão dos Rodellas, delictos q' se cometem nelle; e dissolução com q' vive o M.e de campo do Presidio daz Alagoas. In: ENNES, Ernesto. A guerra dos Palmares. Rio de Janeiro: Cia. Editora Nacional, 1938. p. 349-351.

DEZCRIPÇÃO do certão do Peauhy Remetida ao Illm. ${ }^{\circ}$ e Rm. ${ }^{\circ}$ S. ${ }^{o r}$ Frei Francisco de Lima

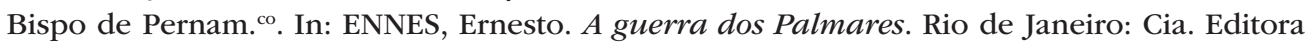
Nacional, 1938. p. 370-389. 
DIÃRIO da viagem de regresso para o Reino, de João da Maia da Gama, e de inspecção das barras dos rios do Maranhão e das capitanias do Norte, em 1728. Transcrito em MARTINS, F.A. OLIVEIRA. Um herói esquecido (João da Maia da Gama). Vol. 02. Lisboa: Divisão de Publicações e Biblioteca Agência Geral das Colónias, 1944. p. 05-114.

FALLA, que derigio a Assemble'a Legislativa do Piauhy no acto da sua instalaçam o presidente da Província no dia 04 de maio de 1835. p. 08. Disponível em <http://www.crl.edu>, acesso em 02 abril 2010.

GARDNER, George. Viagem ao Interior do Brasil. São Paulo: Edusp, 1975.

PITA, Sebastião da Rocha. História da América portuguesa. Belo Horizonte: Itatiaia; São Paulo: Edusp, 1976.

SILVA, Antonio Moraes. Diccionario da lingua portugueza - recompilado dos vocabularios impressos ate agora, e nesta segunda edição novamente emendado e muito acrescentado. Lisboa: Typographia Lacerdina, 1813. p. 126. Disponível em <http://www.brasiliana.usp.br>, acesso em 14 jan. 2015.

SOBRE se criarem Juizes nas freguezias do Certão para administrarem Justiça, e os corregedores serem obrigados a vizita-los uma vez cada triennio. Anais da Biblioteca Nacional do Rio de Janeiro. Vol XXVIII. Ano 1906. Rio de Janeiro, 1908. p. 343-344.

SOUSA, Gabriel Soares de. Tratado descritivo do Brasil em 1587. São Paulo: Cia. Editora Nacional; Edusp, 1971.

SPIX, J. B. von; MARTIUS, C. P. F. Viagem pelo Brasil: 1817 - 1823. Rio de Janeiro: Imprensa Nacional, 1938.

TERMO de eleiçãp q' fizerão os moradores do certão do Piauhi; do lugar, p. ${ }^{\text {a }}$ se fazer a Ig. ${ }^{\text {ia }}$ de Nossa Senhora da Victoria. In: ENNES, Ernesto. A guerra dos Palmares. Rio de Janeiro: Cia. Editora Nacional, 1938. p. 364-365.

TERMO de Benção da Nova Capella e poçe q' se deu ao R. ${ }^{\circ}$ cura. In: ENNES, Ernesto. $A$ guerra dos Palmares. Rio de Janeiro: Cia. Editora Nacional, 1938. p. 368-369.

VIDE, Sebastião Monteiro da. Constituições Primeiras do Arcebispado da Babia, feitas e ordenadas pelo ilustríssimo e reverendíssimo D. Sebastião Monteiro da Vide. Brasília: Senado Federal, Conselho Editorial, 2011.

\section{LIVROS, ARTIGOS E TESES}

ARAUJO, Renata Malcher de. Desenhar cidades no papel e no terreno: cartografia e urbanismo na Amazónia e Mato Grosso no século XVIII. In: OLIVEIRA, Francisco Roque; VARGAS, Héctor Mendonza (coord.). Mapas de metade do mundo. A cartografia e a construção territorial dos espaços americanos: séculos XVI a XIX. Lisboa: Centro de Estudos Geográficos - UL, 2010. p. $179-210$. 
O Piauí e sua cartografia. In: IV Simpósio Luso-Brasileiro de Cartografia Histórica, 2011, Porto.

. Às portas do paraíso. Mais que aldeia, menos que vila, o purgatório da utopia. In: ACCIAIUOLI, Margarida (org.). Arte E Utopia. Lisboa: CHAIA-UE/DINÂMICA-CET-IUL/FCSHUNL, 2013. p. 88-100.

ARRAES, Damião Esdras Araújo. Currais de reses, currais de almas: urbanização do sertão nordestino entre os séculos XVII-XIX. 2012. Dissertação (Mestrado) - Faculdade de Arquitetura e Urbanismo da Universidade de São Paulo, São Paulo, 2012.

ARRAES, Esdras. Rio dos currais: paisagem material e rede urbana do rio São Francisco nas capitanias da Bahia e Pernambuco. Anais do Museu Paulista: História e Cultura Material, São Paulo,v. 21, n.2, p. 47-77, jul.-dez., 2013. Disponível em <http://dx.doi.org/10.1590/S010147142013000200003>.

ARRAES, Esdras. Entre reses e almas: questões sobre urbanização, arquitetura e arte das missões jesuíticas dos sertões das capitanias do Norte. Revista Pós, São Paulo, v. 21, n. 36, dez. p. 95, 2014. DOI: <http://dx.doi.org/10.11606/issn.2317-2762.v21i36p84-100>.

AZZI, Riolando. A instituição eclesiástica durante a primeira época colonial. In: HORNAERT, Eduardo et al. História da Igreja no Brasil: ensaio de interpretação a partir dos povos: primeira época, período colonial.5 ed. Petrópolis: Vozes, 2008.

BANDEIRA, Luiz Alberto Moniz. O feudo: a Casa da Torre de Garcia d'Ávila. Da conquista dos sertões à independência do Brasil. Rio de Janeiro: Civilização Brasileira, 2000.

BOSCHI, Caio César. Os leigos e o poder (irmandades leigas e política colonizadora em Minas Gerais). São Paulo: Ática, 1986.

BURKE, Peter. O que é História cultural? Rio de Janeiro: Jorge Zahar , 2005.

COSTA, F. A. Pereira da. Cronologia histórica do estado do Piauí. Rio de Janeiro: Artenova, 1974.

COSTA, Lúcio. A arquitetura jesuítica no Brasil. Revista do Patrimônio Histórico e Artístico Nacional, Rio de Janeiro,v. 5, 1941. p. 11-98.

DELSON, Roberta Marx. Novas vilas para o Brasil Colônia: planejamento espacial e social no século XVIII. Brasília: Alva-Ciord., 1997.

DERNTL, Maria Fernanda. Método e arte: criação urbana e organização territorial na capitania de São Paulo, 1765-1811. 2010. Tese (Doutorado) - Faculdade de Arquitetura e Urbanismo da Universidade de São Paulo, São Paulo, 2010.

ENNES, Ernesto. A guerra dos palmares. Rio de Janeiro: Cia. Editora Nacional, 1938.

FERREIRA, Murilo Cunha (coord.). Cidades do Piauí testemunhas da ocupação do interior do Brasil durante o século XVIII: conjunto histórico e paisagístico de Oeiras - dossiê de tombamento.Teresina: IPHAN/Regional do Piauí, 2010. 
FONSECA, Cláudia Damasceno. Arraiais e vilas d'el rei: espaço e poder nas Minas setecentistas. Belo Horizonte: Editora UFMG, 2011

FREIRE, Felisbelo. História de Sergipe. 2 ed. Petrópolis: Vozes, 1977.

FRIDMAN, Fania. Donos do Rio em nome do rei: uma história fundiária da cidade do Rio de Janeiro. 2 ed. Rio de Janeiro: Garamond, 1999.

HESPANHA, António Manuel. Porque é que foi “portuguesa”a expansão portuguesa? Ou O revisionismo nos trópicos. Conferência proferida na sessão de abertura do Colóquio $O$ espaço atlântico de Antigo Regime: poderes e sociedades". Org. Pelo CHAM-FCSH-UNL/IICT, Lisboa, 2 a 5 de Novembro de 2005.

KANTOR, Íris. Cartografia e diplomacia: usos geopolíticos da informação toponímica (17501850). Anais do Museu Paulista: História e Cultura Material, São Paulo, n. 17, v. 2 , jul.-dez., 2009.

LEITE, Serafim. História da Companhia de Jesus. Tomo V. Rio de Janeiro: Imprensa Nacional, 1945.

MAGALHÃES, Joaquim Romero. Concelhos e organização municipal na Época Moderna. Miunças 1. Coimbra: Imprensa da Universidade de Coimbra, 2011.

MARX, Murillo. Cidades no Brasil, terra de quem? São Paulo: Edusp; Nobel, 1991.

MONTEIRO, John M. Tupis, Tapuias e historiadores: estudos de História Indígena e do Indigenismo. 2001. Tese (Livre docência) - Instituto de Filosofia e Ciências Humanas, Universidade Estadual de Campinas, Campinas, 2001.

NOGUEIRA, Patrícia Moreira. Considerações sobre os relatórios de visitas ad limina apostolorum do bispado de Pernambuco (1680-1746): aspectos históricos e historiográficos. Revista Fontes, Unifesp, n.2, p.10-16, 2015. Disponível em <http://www.revistadefontes. unifesp.br>, acesso em 18 out.2015.

OLIVEIRA, Dom Oscar de. Os dízimos eclesiásticos do Brasil. Estudos 3. Belo Horizonte: Estudos, 1964.

POMPA, Maria Cristina. História de um desaparecimento anunciado: as aldeias missionárias do São Francisco, séculos XVIII - XIX. In: OLIVEIRA, João Pacheco de (org.). A presença indigena no Nordeste: processos de territorialização, modos de relacionamento e regimes de memória. Rio de Janeiro: Contra Capa, 2011. p. 267.

PUNTONI, Pedro. A guerra dos bárbaros: povos indígenas e a colonização do sertão do Nordeste do Brasil, 1650 - 1720. São Paulo: Hucitec; Edusp, 2002.

RUBERT, Arlindo. Historia de la Iglesias en Brasil. Madrid: Editorial Mapfre, 1992.

SARAIVA, Maria da Graça Amaral Neto. Os rios e as cidades. In: MATOS, Artur Teodoro de; MEDEIROS, Carlos Laranjo. Povos e Culturas (A cidade em Portugal: onde se vive). n0 02. Lisboa: Universidade Católica Portuguesa, 1987. p. 481-509. 
SILVA, Ana Cristina Nogueira da; HESPANHA, António Manuel. O quadro espacial. In: MATTOSO, José. História de Portugal. Quarto volume - O Antigo Regime (1620-1807). Lisboa: Estampa, 1998.

\section{SÍTIOS CONSULTADOS}

<http://www.revistafontes.unifesp.br>. Acesso em 18 out. 2015.

<http://www.bbm.usp.br>. Acesso em 30 nov. 2015.

<http://www.crl.edu>. Acesso em 02 abr. 2010.

<http://www.bn.br>. Acesso em 03 fev. 2010.

Artigo apresentado em 11/02/2016. Aprovado em 04/04/2016. 